\title{
From Enlightenment to Cyborgs
}

\section{Claudio Messori}

Str. Villaggio Prinzera 1, Fraz. Boschi di Bardone, Terenzo, Italy

Email: messori.claudio@gmail.com

How to cite this paper: Messori, C. (2017) From Enlightenment to Cyborgs. Open Access Library Journal, 4: e4033. https://doi.org/10.4236/oalib.1104033

Received: October 14, 2017

Accepted: November 14, 2017

Published: November 16, 2017

Copyright $\odot 2017$ by author and Open Access Library Inc.

This work is licensed under the Creative Commons Attribution International License (CC BY 4.0).

http://creativecommons.org/licenses/by/4.0/
Abstract
The decline of the feudal system and the progressive rise of the medieval
bourgeoisie to power roles and government functions, leads the West $\left(17^{\text {th }}\right.$
century) to theorize and assume a materialistic, reductionist and mechanistic
model of thought, based on a privileged, tendentially exclusive, relationship
with Science (Galilean scientific method), technique and technology. This pa-
per takes into account the historical, sociological, and anthropological ele-
ments (such as the unlimited perfectibility of humanity advocated by the
French Enlightenment and the mechanization of the production cycle envi-
saged by English proto-liberalism) of this paradigmatic revolution, which
more than others help us understanding the causal process that led to con-
temporary techno-centrism 4.0. It is highlighted that thanks to the interweav-
ing between the ideals of the French Enlightenment, with its two souls (Naturophilus and Technophilus), and the Anglo-Saxon entrepreneurial foresight (proved successful with the Industrial Revolution 1.0), takes shape the Positivist paradigm, and with it the Positivist secular religion, whose affirmation and diffusion generate a stream of widely shared thought throughout the West, i.e. Eugenics, which radicalizes the most ambivalent (pseudo-scientific) and reactionary (philocolonialist) instances of Enlightenment and Positivism, leading to a series of crimes against the person and against humanity, which will result in the mass eliminations conducted, in particular but not only, by Nazi-fascism and Stalinism (two totalitarian regimes that share the same Positivist roots and the same passion for Eugenics thought). It is highlighted that the heart of the industrialization process begins to throb in factories, where the introduction of mechanical systems into the production cycle triggers the man-machine integration process, which soon becomes the fulcrum, the economic, social and cultural driving factor of the western civilization. It will be thanks to the evolution of the mechanical systems employed in the production chains and to the establishment of the Liberalist economic model, that between the second and third Industrial Revolution consolidates the alliance between academic, industrial and military (the academic/industrial/military iron triangle). An alliance destined to play a decisive role in the two World 
Wars of the $20^{\text {th }}$ century and in all subsequent warfare. The present paper therefore highlights how the two World Wars have exponentially increased western scientific and technological development, which once transferred from the military to the civilian sector, has taken off the Industrial Revolution 3.0. Thanks to the Second World War, the US academic/industrial/military iron triangle is strengthened and becomes the world leader in scientific, military, economic and technological development. The computerization of society and the development of so-called Artificial Intelligence are side effects of the new way of conceiving the integrated relationship between soldier and armament, matured in the US military sector during World War II. The soldier-armament automation model that emerged from that war experience, and the enormous technical and technological developments that have taken place, paved the way for the creation of man-machine hybrids (cyborgs) and for the robotization of society (Industrial Revolution 4.0), intended to be a complementary effect of contemporary warfare. In conclusion, the birth of a neo-positivist secular religion, inspired by a scientific and hermaphroditic divinity, called Universal Consciousness, is contemplated.

\section{Subject Areas}

Anthropology, History, Sociology

\section{Keywords}

Enlightenment Homme Nouveau, Enlightenment Naturophilus \& Technophilus Soul, Man-Machine Integration Process, Progressive Techno-Scientism, Secular Religion, Eugenics, Academic/Industrial/Military Iron Triangle

\section{From the Enlightenment Homme Nouveau to the Positivist Industrial Revolution}

The necrophilous person is driven by the desire to transform the organic into the inorganic, to approach life mechanically, as if all living persons were things. All living processes, feelings, and thoughts are transformed into things.

Erich Fromm The Heart of Man (1964)

The revolutionary change in the relationship with the technique and technol$o g y$, which it has been promoted by, and of which is bearer Western civilization, by adopting the Enlightenment ( $18^{\text {th }}$ century) and Positivist ( $19^{\text {th }}$ century) paradigm, in the definition of its own identity system [1], it has transformed, in a period of just 300 years, and will transform dramatically, the dynamics and structure of the societies subjected to this change and constrained to the market laws

${ }^{1}$ Fromm, E. (2011) The Heart of Man, Lantern Books, p. 37. 
that govern it. From now on, all social, political, cultural, and even religious life revolve around technical and technological knowledge. This is the peculiarity and the distinctive character of the contemporary Western paradigm, which distinguishes it from all other paradigmatic models, at the same time its strength and its limit.

Starting from the advent of the Industrial Revolution 2.0 (second half of $19^{\text {th }}$ century) to date, the power accrued by the techno-centrism grew exponentially. In the wake of the pressing development, first military and then civil, of increasingly versatile and high-performance technical and technological solutions, the technological revolution, whose heart began to pulsate in the factories, has succeeded in imposing a new set of social values, where the patrimony of capacity, possibilities and tendencies, phylogenetic and epigenetic, which give identity and dignity to the human being ${ }^{2}$, is constrained, and subordinated, to the abilities, possibilities and trends that depend on the technological contribution.

In particular, the current Industrial Revolution 4.0, promoted by the Vannevar Bush's (1947) "academic/industrial/military iron triangle", is pointing to a radical change in the man-machine integration process, theorized by Enlightenment and applied at first by the Industrial Revolution 1.0, which opens serious questions about both the fate of human anthropological status and the future of human civilization. In the new contemporary hyper-technological scenario, human beings must no longer only adapt to, and conform to the use of, more or less sophisticated mechanical systems.

Today, in order to be competitive and socially fit, human subjects, especially the new generations, must undergo a real techno-genetic mutation that forces them to merge and confuse themselves with platforms, systems, devices and artificial solutions that do not add, but eventually subtract, value to their humanity.

What, indeed, takes enormous value and prestige, is the (compulsive) use of the new technologies, thanks to which it is acquired a digital identity that elevates the users grown with it to the status of digital natives.

Digital identity is an expression linked to the phenomenon of Digital Transformation (D.T.), or rather Digital Mutation (D.M.), which is rapidly investing the technologically advanced societies, involving, above all, the way in which it is communicated, consumed, informed about the world, studied and worked (a gradual phenomenon of automation in manufacturing and services is in

${ }^{2}$ It is thanks to the phylogenetic and epigenetic availability of capabilities, possibilities and tendencies that overcome the stereotyped animal behavior that the Homo genus distinguishes itself as the only species capable of deliberately increasing its ability, possibility and tendency to exist. The development of consciousness, symbolizing, oral language, logical-abstract thought and of human knowledge strategies used for this purpose is not present in any other animal species, but it characterizes our [Messori, 2016].

${ }^{3}$ See: Norbert Wiener, "Men, Machines, and the World About", in Medicine and Science, 13-28, New York Academy of Medicine and Science, ed. I. Galderston, New York: International Universities Press, 1954.

http://21stcenturywiener.org/wp-content/uploads/2013/11/Men-Machines-and-the-World-About-b y-N.-Wiener.pdf 
progress, resulting in the extinction of certain types of workers and their jobs $\left.{ }^{4}\right)$. D.T. modify habits, traditions, principles and relationships through the organic evolution of a heterogeneous and combined set of four digital megatrends of technologies: a) mobile (mobile devices, smartphone and tablet); b) big data (data set and information analysis, both current and future, in real time, through structured and unstructured data analysis processes); c) cloud computing (data development and management platforms) and d) social (social networks, online platforms that allow users to create a public or semi-public profile, and interact with other users). All four megatrends subjected to data security issues (hacking).

"Mutation" then is the right term to describe not a transition, but a true techno-genetic modification of people and society that leads to the generation of digital identities, as real as those of the physical dimension and, perhaps, even more powerful than the latter, because digital identity can be shaped according to one's or others' needs, and is not bound to material limits.

The contemporary man-machine integration process offers us pseudo-intelligent cybernetic anthropomorphic systems (robot), man-machine hybrids (cyborg) and new generations of genetically modified organisms. Side effects of a man-machine integration process conceived in the military during World War II. As Frank Rose wrote at the beginning of the ' $80^{\text {s }}$ [2], at the dawn of the Industrial Revolution 3.0: "The computerization of society ... has essentially been a side effect of the computerization of war".

Norbert Wiener (1894-1964) [3], father of modern cybernetics, was one of the scientists who during World War II collaborated on a OSRD project (Office of Scientific Research and Development, the same US government agency that under the leadership of Vannevar Bush [4] also controlled the Manhattan Project, which led to the creation of the first nuclear weapon), from which took shape the idea of obtaining the maximum efficiency, reliability and operational effectiveness in combat, from the integration of man (soldier) and machine (armament) in a single system, in which the human element and the mechanical element merge, from an engineering point of view, into a single structure.

As Wiener writes [the bold in the text is mine]:

The antiaircraft gun is a very interesting type of instrument. In the First World War, the antiaircraft gun had been developed as a firing instrument, but one still used range tables directly by hand for firing the gun. That meant, essentially, that one had to do all the computation while the plane was flying overhead, and, naturally, by the time you got in position to do something about it, the plane had already done something about it, and was not there. It became ${ }^{4}$ In an interview released at the beginning of February 2017 to the free digital news publication Quartz, Bill Gates, co-founder of Microsoft, proposes to amortize the negative consequences that will be on taxation fees for the loss of millions of jobs (i.e., for the loss of revenue from fees levied on employment income), by taxing the robots that will replace the human workers in exuberance: "Certainly there will be taxes that relate to automation. Right now, the human worker who does, say, $\$ 50,000$ worth of work in a factory, that income is taxed and you get tax, social security tax, all those things. If a robot comes in to do the same thing, you'd think that we'd be taxing the robot at a similar level'. 
evident-and this was long before the work that I did-by the end of the First World War, and certainly by the period between the two, that the essence of the problem was to do all the computation in advance and embody it in instruments which could pick up the observations of the plane and fuse them in the proper way to get the necessary result to aim the gun and to aim it, not at the plane, but sufficiently ahead of the plane, so that the shell and the plane would arrive at the same time as induction. I had some ideas that turned out to be useful there, and I was put to work with a friend of mine, Julian Bigelow. Very soon we ran into the following problem: the antiaircraft gun is not an isolated instrument. While it can be fired by radar, the equivalent and obvious method of firing it is to have a gun pointer. The gun pointer is a human element, this human element is joined with the mechanical elements. The actual fire control is a system involving human beings and machines at the same time. It must be reduced, from an engineering point of view, to a single structure, which means either a human interpretation of the machine, or a mechanical interpretation of the operator, or both. We were forced-both for the man firing the gun and for the aviator himself-to replace them in our studies by appropriate machines. The question arose: How would we make a machine to simulate a gun pointer, and what troubles would one expect with the situation?

Industrial Revolution 4.0 it is touted, by all means available to the contemporary academiclindustriall military iron triangle, as an Eldorado of promises and opportunities intended to increase the Private \& Public Good, sponsored by the idea that what is natural it can be progressively replaced by what is artificial, claiming that the human model to be pursued must adhere to the hyper-technological engineered model of man-machine conceived for military purposes.

\subsection{The Enlightenment Year Zero}

I should like you to consider that these functions (including passion, memory, and imagination) follow from the mere arrangement of the machine's organs every bit as naturally as the movements of a clock or other automaton follow from the arrangement of its counter-weights and wheels.

Descartes Treatise on Man $(1633)^{5}$

Between the $18^{\text {th }}$ and $19^{\text {th }}$ century, when the average age of Europeans ranged from 35 to 40 years, and when [translation is mine] "the animal placed higher, which was usually thought to be the monkey, was related with the type of man placed lower, usually being considered the black' (George L. Mosse) [5], the

${ }^{5}$ As quoted in: Lopez-Cajun, Ceccarelli, M. (edited by) (2016) Explorations in the History of Machines and Mechanisms: Proceedings of the Fifth IFToMM Symposium on the History of Machines and Mechanisms; Koetsier, T.: Lewis Mumford Revisited; Springer, p. 178. 
West has worked out and adopted, for the first time in the oral and written history of humanity, an identity model that exempts the priestly and noble caste from their millennial function of governing the souls and the bodies, to transfer the mandate of the government on the people in the hands of a new ruling class, the bourgeoisie, the historical heir of the values and interests earned by the Medieval Arts and Crafts Corporations, headed by its most influential and wealthy leaders, the Renaissance bankers.

For this purpose, Enlighteners intellectuals ("une assemblée de philosophes occupés à préparer le bonheur du monde", Pierre Louis Manuel, 1792) have retroactively excluded from the perspective of dominant knowledge, all that does not concern the sensitive world, establishing a materialistic, reductionist and mechanistic paradigmatic model, according to which only what can be rationally explained, and from which it is possible to obtain a material profit, that is, only what can be calculated, measured, reproduced and eventually marketed, it is worthy of attention and can be considered real. Everything else belongs to a fictitious plane of reality, as the mind (res cogitans vs res extensa), or is the result of fantasies and superstition.

The retroactive effect applied to the new categories of reality gives the Age of Enlightenment the character of a watershed between a major history, which began with the formulation and the use of physical laws translatable in a universal and constant quantitative language ( $\rightarrow$ Galilean scientific method ${ }^{6}$ ), functional to the catechism of bourgeois entrepreneurial profit, and a minor history, written over time based on the categories of reality generated in other places and at other times, by other human communities, through forms of knowledge other than that adopted by Enlightenment.

To fall under the guillotine of the Enlightenment year zero, it has been not just the head of the noble caste, and with them the credibility of the mysteries of the Catholic faith ( $\rightarrow$ consubstantiality), instrumentally invoked by the priestly caste, the one of the Holy Roman Church that starting from the $12^{\text {th }}$ century up to the mid- $15^{\text {th }}$ century first tortured and then burned millions of women accused of witchcraft by the Holy Inquisition; the one that between the $14^{\text {th }}$ and $16^{\text {th }}$ century undertook, with the complicity of the feudal nobility, a thriving business based on the buying and selling of plenary indulgence.

The excellent victim of the Enlighteners reformers it has been the centrality of the role assigned to Man by the founding core of all the internal representations of the external reality and of all systems of values, with their respective relational, social, cultural, cultic, utilitarian and non-utilitarian systems, generated by human communities from the Middle Paleolithic onwards. This role, emerged from the human psychological birth (Middle Paleolithic) [6] [7], is symbolically expressed in the form of the Axis Mundi, the Axis that connects what stays above (immeasurable) with what stays below (measurable), the archetypal triad that orientes human existence (this is also the meaning of the symbolism of the ${ }^{6}$ Which is divided into four phases, two inductive and two deductive: observation, hypothesis, experimentation, mathematization. 
cross [8] [9]), assigning to it a precise position in the hierarchical relationship with the unmanifested world ( $\rightarrow$ immaterial, intangible, incorporeal dimension) and with the manifested world ( $\rightarrow$ material, tangible, corporeal dimension) such that: what stays above is the Sky, what exceeds and overcomes the ordinary world of forms and changes (instability and impermanence of forms and their shadows does not allow to consider them as real, but as almost real: only the rhythm of the movement that penetrates them elevates them to reality [8]), the placeless of alterity, of the unborn, of Non-Being, below is the Earth, the underlying, the sensitive world, the place of identity, individuation, of the born, of Being, in the middle is the Man, the medium that walks upright on Earth trying to accord his earthly identity-immanence with the alterity-transcendence of the Sky (it will be only from the Upper Paleolithic that the primordial image from which flows the Man-as-medium, produced during the Middle Paleolithic by the imaginific function [7], and gradually covered with magical and symbolic content, will be subject to a slow processing process, marking the step towards the formulation of religious norms and beliefs, which have prescribed the times and the ways of cultural and social transformations, to which Neolithic and post-Neolithic civilizations have met; a prescriptive role that is still present, where social systems are governed by sacred rules, norms, institutions and beliefs).

\subsection{The Homme Nouveau}

All the most significant concepts of the modern doctrine of the State are secularized theological concepts.

Not only because of their historical development, since they have passed on to the doctrine of the State from theology, such as the omnipotent God who has become the almighty legislator, but also in their systematic structure, whose knowledge is necessary for a sociological consideration of these concepts.

Carl Schmitt [my translation] Teologia politica. Quattro capitoli sulla dottrina della sovranità $(1922)^{8}$

In its place, in place of the archetypal symbolic content that led to interpret the human being as an elective medium between Earth and Sky, the $18^{\text {th }}$ century Enlighteners reformers introduces the figure of Homo Technologicus (Homme Machine, J.O. de La Mettrie, 1747), a New Man (Homme nouveau) who interprets the world and himself as a mosaic of moving mechanical components, dri-

\footnotetext{
${ }^{7}$ As Carl Gustav Jung writes: My views about the 'archaic remnants', which I call 'archetypes' or 'primordial images', have been constantly criticized by people who lack a sufficient knowledge of the psychology of dreams and of mythology. The term 'archetype' is often misunderstood as meaning certain definite mythological images or motifs, but these are nothing more than conscious representations. Such variable representations can not be inherited. The archetype is a tendency to form such representations of a motif-representations that can vary a great deal in detail without losing their basic pattern. [Jung, C.G. (1968) Man and His Symbols, Mass Market Paperback].

${ }^{8}$ In: Miglio, G., Schiera, P. (edited by) (1972) Le categorie del “politico", Ed. Il Mulino, p. 61.
} 
ven by energy input, which can be measured, calculated, controlled, modified, enhanced, reproduced.

For the Enlighteners first, and for the Positivists then, the Universe is a mechanical system of solid objects (res extensa) that fill portions of an otherwise empty space, placed in reciprocal relation according to laws of motion that, at least in principle, are calculable. On this Universe reigns an Enlightenment God, a Deus otiosus. A Logical God as its predecessor, the one who was made-man-in-Christ with a dogma of faith ${ }^{9}$ [1] [8] [9] [10], thoroughly decontaminated by any trace of transcendence, a mechanical God, a Great Clock Watcher. A Supreme Being, the Deus Absconditus of the Esoterics, the Great Architect who thanks to the sublime art of mathematics and geometry has created everything that populates space between Earth and Sky without leaving anything to chance. The Whole, argue the Enlighteners, was calculated according to a mathematical cause-effect design, to be handed over to the hands of the Homme nouveau, elected by the mechanical God as the only being of creation in which it is fully infused the res cogitans, i.e., to the hands of the educated-wellbeing-white-male bourgeois, dedicated to the study, domestication, empiricist and utilitarian manipulation of the res extensa.

A Homme nouveau who chooses to exclude ( $\rightarrow$ Cartesian dualism) the immaterial, fictitious dimension ( $\rightarrow$ res cogitans), subjectively lived and not circumscribable by rationality (not translatable in a universal and constant quantitative language such as that used to describe the formal world $\rightarrow$ res extensa), from his own perspective of knowledge ${ }^{10}$.

A New man destined to rule and to be ruled by the Reason (Pure?) of the Science of what is useful and constructive; the renewed face of the metaphysics applied for practical purposes [1] [7] [10] of Aristotelian memory, which can radically modify the structure of human existence and human being itself; the place where lie the Ideas and the Universals, the logical working plan of the methodical doubt, the fulcrum of the analytic and deductive Cartesian procedure,

\footnotetext{
${ }^{9}$ Having made the immortal mortal and the mortal immortal (the consubstantiality of the Christological pericoresis, basis of the dogma of the Trinity), it is a metaphysical operation applied for practical purposes unique in its kind, which fully accept the Aristotelian instance: what concerns the Logos (in Plato the Hyperuranic Sky of Ideas), the Prime (Immobile) Movers (in Aristotle the metaphor of the anti-historicity of metaphysics), however sublime may it be, is by definition alien to issues of practical order and therefore not-helpful, so we, the experts of the art and of the power tool of the logos (Dialectics, the tight application of logic, and Rhetoric, the ability to use the speech as the key to any authority of the state), we turn to the exclusive use of the Reason of Ideas (of Mathematics and Geometry).

${ }^{10}$ Surprisingly, the contemporary Homme nouveau, whose Ego is affected by a genetically modified form of elephantiasis, has decided to investigate the res cogitans with the same tools used to tame the res extensa. No matter if res cogitans is not translatable in a universal and constant quantitative language such as that used to describe the formal world, we can make that happen. How? We know for a long time that chemicals and chemical processes (CPs) affect the condition and activity of the Central and Peripheral Nervous System (CPNS). Today we know that neuro-electrochemical processes (NECPs) are associated with neuro-electromagnetic phenomena (NEMP) that also affect the condition and activity of CPNS. We can assume that there is an equivalence relationship between mental activity on the one hand, and CPs, NECPs and NEMP on the other. That is to say, e.g., that to each portion of an EEG path, it corresponds a portion of thought. Which is false: a finger pointing at the moon is not the moon.
} 
through which indubitable, absolute propositions can be generated.

A New Man embodied by the $17^{\text {th }}$ and $18^{\text {th }}$ century bankers-merchantscraftsmen, who no longer want to be second to anyone, neither to the clergy nor to the feudal nobility. The Entrepreneurial and Liberalist bourgeoisie, which has more than all been able to take advantage and impulse from the effects of the Protestant Reformation ( $16^{\text {th }}$ century), the circulation of ideas promoted by the invention of the mobile printing press (1455) and the lesson of economics finance given to contemporaries and posters by the Fugger family $\left(16^{\text {th }}-17^{\text {th }}\right.$ century).

A Man-Machine that will capitalize on technological resources (second half of the $18^{\text {th }}$ century, England, Industrial Revolution 1.0), i.e. on the knowledge and know-how related to the intentional creation, production and application of manuals and/or instrumental techniques (procedures), aimed at fulfilling the anthropic needs [11], by introducing and promoting the mechanization of the production cycle.

A Man-Machine that during the hundred years separating the Industrial Revolution 1.0 from the Industrial Revolution 2.0, submits the credibility of the Trinity and the authority of the Catholic priestly caste to a process of secularization, still underway, which traces the boundaries of their interference in earthly private and public affairs, subordinates them to the interests set by the bourgeoisie for the Private \& Public Good ${ }^{11}$, and raises them in open competition with a new form of divine law, established by scientific criteria, and with a new category of representatives of the sacred (secularized), the scientists, delivering to history the epic of modern Liberalist and technological revolution, where "Government has no other end but the preservation of property"12 (John Locke, 1632-1704).

The Hommes nouveau, the libertines-entrepreneurs of which narrates the Divine Marquis de Sade (1740-1814), supporters of the practice of the laissez-faire ${ }^{13}$ and of the disintegration of religious worship, in favor of replacing the sacred symbols of Christianity with erotic images, metaphors of an eroticism used in a pretestuous way, as a sales strategy, as an advertising technique to entice the customer to buy the marketed products, to submit him to an orgy of images, arguments, demonstrations, information that will give him the sense of a system of

${ }^{11}$ Public Good is the current translation of the early Enlightenment's bonheur commun, a translation that is a fallacious generalization of the French original meaning, i.e. French people's happiness.

${ }^{12}$ Locke, J. (1689) Second Treatise, $\$ 94$.

http://press-pubs.uchicago.edu/founders/documents/v1ch17s5.html

${ }^{13}$ It is interesting to note that the laissez-faire metaphor is the $17^{\text {th }}$ century French translation of the Chinese $w u$-wei, an expression imported from China in Europe by Jesuit missionaries (16 ${ }^{\text {th }}$ century) that belongs to Taoism, where it assumes the meaning of "action-without-action" (the wise man acts in accordance with the Law of Tao, or Dao, which corresponds to Vedic Dharma and to Aristotle's Prime (Immobile) Movers, i.e., he acts in accordance with what transcends any egoic principle), and was then borrowed by Confucianism, to become a metaphor of "government without government", i.e. the Tao (embodied by the Emperor) Law is translated into norms and rules dictated by Tradition (history is a sequence of contingent events on which Tradition reigns), to become a principle of government eternal and absolute, immovable and indestructible as a mountain.

On the sequence of historical events ranging from the introduction of wu-wei to Europe to its transformation into laissez-faire, see: Gerlach, C. (2005) Wu-Wei in Europe. A Study of Eurasian Economic Thought, London School of Economics. http://hsozkult.geschichte.hu-berlin.de/daten/2005/gerlach_christian_wu-wei.pdf 
values in which carnal violence and the purchase of a commodity are equivalent, in which the cold representation of a corporal mechanics turns out to be metaphorical of something else.

Something else to which Liberalism assigns a market value.

Doctrine and economic policy developed starting from the $17^{\text {th }}$ century, as a reaction to mercantilist theories (and economic policies), which had spread widely in Europe between the $17^{\text {th }}$ and $18^{\text {th }}$ century, Liberalism finds its full formulation in England with Adam Smith (1723-1790). Unlike the mercantilist doctrines, that affirm the benefits of state protectionist economic policies, Liberalism is founded on complete freedom of production and goods and services trade, both internally and abroad, thus opposing any form of interventionism and protectionism in the economic field by the State. In fact, the latter must confine itself to guaranteeing economic freedom and to meet the needs of the community by legal rules only when they can not be satisfied privately.

With different shades, modes and socio-political implications, Liberalism is based on the principle understood by the metaphor of laissez faire, an expression attributed to the French merchant Legendre (1680) but passed to history as laissez faire, laissez passer (let it go, let it pass) thanks to the physiocratic proto-liberalist JCM Vincent de Gournay (1712-1759). The principle to which the laissez faire refers, states that the optimum functioning of the economic system flows from the free initiative of the single individuals (which means, first of all, the private property of means of production), which in the pursuit of their interest must not be conditioned or hindered by any external constraint (i.e., imposed by the interference of the State). When interpreted in Locke's direction (John Locke, 1632-1704), the laissez faire, laissez passer leads to the exaltation of the virtues of a free market conceived as a system in its own right, independent, self-determined and self-sufficient, a system that does not have to be influenced or controlled by (but which can influence and control) the cultural and political context within which it operates. As the neo-liberalist Friedrich von Hayek will write [12]: Economic control is not merely control of a sector of human life which can be separated from the rest, it is the control of the means for all our ends. And whoever has sole control of the means must also determine which ends are to be served, which values are to be rated higher and which lower-in short, what men should believe and strive for.

Instead, when interpreted in the Smithian sense, the Liberalist laissez faire, laissez passer must take into account that freedom of market can only be achieved in a cultural and political context in which the freedom of the individual and the legal certainty is guaranteed.

\subsection{The Two Souls of Enlightenment}

... modernity abolishes religion, as a system of meanings and engine of human efforts, but at the same time creates the space-time of a utopia which in its very structure 
has an affinity with the religious issues of fulfillment and salvation.

Danièle Hervieu-Léger ${ }^{14}$ [my translation]

The establishment of the Enlightenment paradigm marks the tipping point of the downward trend that has gone to meet, with the establishment of the dogma of the consubstantiality (Homoousion) of the Son with the Father (Nicaea Council, $325 \mathrm{AD}$ ), the little that remained of unthinkable, non-edible by the senses, unassailable by the fork of emotions and the knife of discriminative and speculative thinking ${ }^{15}$, in the western internal representation of external reality. What is conveyed to history is a materialistic vision of the world, with some pantheistic reminiscence and some inclination towards inner sentimental experiences, such as those preached by the pietism of Jakob Spener (1635-1705), governed by two souls, the two souls of Enlightenment.

Starting from different but complementary arguments, the two souls of Enlightenment state that the future of humanity is placed, thanks to a natural order for one of the two, the Naturophilus soul, and to a mechanical order for the other, the Technophilus soul, in the hands of Western civilized peoples ${ }^{16}$, i.e. in the

\footnotetext{
${ }^{14}$ Hervieu-Léger, D., Champion, F. (1986) Vers un nouveau christianisme?: introduction à la sociologie du christianisme occidental, Sciecies humaines et religions, 17, 187-227.

${ }^{15} \mathrm{~A}$ condition that the Dominican Meister Eckhart (1260-1328 AD) expresses in this way: Now observe: God is nameless because none can say or understand anything about Him. Concerning this a pagan master says that what we understand or declare about the first cause is more what we ourselves are than what the first cause is, because it is above all speech or understanding. If I now say God is good, it is not true; rather, I am good, God is not good. I will go further and say I am better than God: for what is good can become better, and what can become better can become best of all. Now God is not good, therefore He cannot become better. And since He cannot become better, therefore He cannot become best, for these three, good, better, and best, are remote from God, since He is above them all. Thus, too, if I say God is wise, it is not true. I am wiser than He. So too if I say God is a being, that is not true: He is a transcendent being, and a superessential nothingness. St. Dionysius says the finest thing one can say about God is to be silent from the wisdom of inner riches. So be silent and do not chatter about God, because by chattering about Him you are lying and so committing a sin. So, if you want to be without sin and perfect, don' t chatter about God. Nor should you (seek to) understand anything about God, for God is above all understanding. One master says, 'If I had a God 1 could understand, I would no longer consider him God.' So, if you understand anything of Him, that is not He, and by understanding anything of Him you fall into misunderstanding, and from this misunderstanding you fall into brutishness, for whatever in creatures is uncomprehending is brutish. So, it you don't want to become brutish, understand nothing of God the unutterable.

- 'Oh, but what should I do then?' You should wholly sink away from your youness and dissolve into His Hisness, and your' your's' and His 'His' should become so completely one 'Mine' that with Him you understand His uncreated self-identity and His nameless Nothingness. [O’C Walshe, M. (translated by) (2009) The Complete Mystical Works of Meister Eckhart, Herder \& Herder Book, p. 463. https://philocyclevl.files.wordpress.com/2016/10/meister-eckhart-maurice-o-c-walshe-bernard-mcgi nn-the-complete-mystical-works-of-meister-eckhart-the-crossroad-publishing-company-2009.pdf] ${ }^{16}$ Will not every nation one day arrive at the state of civilization attained by those people who are most enlightened, most free, most exempt from prejudices, as the French, for instance, and the Anglo-Americans? [Caritat de Condorcet, M.J.A.N. (1794) Outlines of an historical view of the progress of the human mind, Tenth Epoch, Future Progress of Mankind. http://oll.libertyfund.org/titles/condorcet-outlines-of-an-historical-view-of-the-progress-of-the-hum an-mind\#lf0878_head_013]
} 
hands of the French and English $18^{\text {th }}$ century bourgeois class and their allies and descendants.

The roots of the Naturophilus soul, fish in the cultural background of hermetic-rosicrucian-masonic-esoteric origin [13] (which inspired the radical Jacobinism, and which will inspire both Auguste Comte, with his Positivist Church, and the $19^{\text {th }}$ century Conservationist current of the progressive techno-scientism), traceable in Voltaire's and philosophes' deism ${ }^{17}$, in Rosseau's universalistic ideas (crossed by a messianic aspiration to achieve a naturally perfect society) and in Robespierre's naturalistic pantheism ${ }^{18}$.

The Technophilus soul, on the other hand, which will inspire the mechanistic (the mechanical philosophy) and deterministic current of the progressive techno-scientism, it is the product of its time, conceived in the sign of the Cartesian dualism and Newtonian physics, praising, as does Turgot ${ }^{19}$, to progress as a goal to which mankind is inextricably tending (which also meant to legitimize the colonialist, conqueror and racist messianism, who pretended to civilize peoples judged inferior for their institutions or their development), and to the indefinite perfectibility of mankind. A position clearly anticipated by the philosopher and mathematician Marie-Jean-Antoine-Nicolas Caritat, Marquis de Condorcet (1743-1794) [14]: "Such is the object of the work I have undertaken; the result of which will be to show, from reasoning and from facts, that no bounds have been fixed to the improvement of the human faculties; that the perfectibility of man is absolutely indefinite; that the progress of this perfectibility, henceforth above the control of every power that would impede it, has no other limit than the duration of the globe upon which nature has placed us."

The optimism towards science, the confidence in scientific progress, will contributes to determine a very significant conceptual overturn: the category of na-

\footnotetext{
${ }^{17}$ Deism is a religion without mysteries and without rituals, opposed to theism, which only affirms truths permitted and understood by reason: the existence of a Supreme Being, the Deus Absconditus of the esoterics, the Universe creator and legislator, the cause of the world order; the existence of good and evil and of some natural morality; the existence of an immortal soul and/or a post-mortem life. All themes that have come back in vogue thanks to the syncretism that has developed between quantum revolution and, e.g., Oriental philosophies, in particular Buddhism, which has shaped a generation of neo-deists, increasingly convinced of having scientific evidence and philosophical arguments in support to the existence of a Universal Consciousness and a post-mortem life ( $\rightarrow$ NDE). ${ }^{18}$ On 9 November 1792 Condorcet wrote, on the Chronique de Paris newspaper, close to the Girondins political faction, that Robespierre was the "head of a sect", a "preacher" who "rises on the benches and speaks of God and of Providence". And he concluded that Robespierre "is a priest and will be nothing but a priest". And it can not be said that Condorcet was wrong. On 7 May 1794, Robespierre made the Convention decreed the existence of the Supreme Being and the Immortality of the Soul, appointing himself - on the occasion of the Feast of the Supreme Being - the highest priest of this evanescent divinity.

${ }^{19}$ Anne Robert Jacques Turgot, Baron of Laulne (1727-1781), was a major political and intellectual figure in pre-revolutionary France, a well-respected social philosopher and political economist. For Turgot, history is different from nature, as opposed to it, it does not always reproduce in the same way. It is man-made and therefore in history there is progress towards ever greater perfection. This is the cornerstone of Turgot's philosophy of history: progress as a goal to which mankind is inextricably tending. "Reason, Passion and Freedom", these are, for Turgot, the souls of progress (Anne Robert Jacques Turgot, Discourses on Universal History and a Project on Political Geography, 1751).
} 
turalness, the supposed existence of an eternal and immutable natural order, is pressed by that of artificiality, changeability. Nature, including human nature, is thought to be scientifically perfectible, freeing it from the hard law of necessity. What is scientifically modified and artificially built becomes desirable.

\subsection{The Dawn of the Industrialization Process}

The most important effect of machine production on the imaginative picture of the world is an immense increase in the sense of human power (...) no change seems impossible.

Nature is raw material; so is that part of the human race which does not effectively participate in government.

Bertrand Russell History of Western Philosophy (1945) $)^{20}$

Under the propulsive action impressed by the two souls of Enlightenment paradigmatic revolution, two processes of epochal change begin.

One marks the transition from a monarchy of divine right, absolutist, straight by the division of goods and privileges between feudal nobility and clergy, to a constitutional monarchy based on principles, laity and republicans, of equality, freedom and brotherhood, as proclaimed by the Declaration des Droits de P Homme et du Citoyen (1789), which will lead the West to take on forms of parliamentary government, but which will also expose it to the cause of authoritarianism of the Public Good (as is the case of Stalinist and Hitlerian totalitarianism, and as is the case with the current imperialist drift of globalization, which seeks to establish a world-wide public order governed by oligarchic supranational financial interests).

The other process, perhaps even more characterizing of the former and destined to have an even more incisive development and action on the fate of peoples, marks the transition between a protectionist and mercantile economic model, based on agriculture-crafts-trade, to an industrial Liberalism model based on targeted, entrepreneurial, specialized use of mechanical systems driven by inanimate energy sources, which will blur in the process of industrialization ( $\rightarrow$ Industrial Revolution 1.0, England, second half of $18^{\text {th }}$ century) [Figure 1].

Unlike the process of social transformation, whose assumptions and dynamics require complicated and uncertain processing and implementation times, difficult to extract from the Western cultural and historical context, and thus difficult to export to other socio-political contexts, the process of economic transformation has a high degree of penetration into, and adaptability to, socio-cultural environments also very different from the Western one, it guarantees to those who govern it higher profit margins, it facilitates the acquisition of new powerful control tools and it opens perspectives of well-being otherwise

${ }^{20}$ Russell, B. (1945, Fourth Printing) History of Western Philosophy, Simon and Schuster, p. 728. http://www.ntslibrary.com/PDF\%20Books/History\%20of\%20Western\%20Philosophy.pdf 


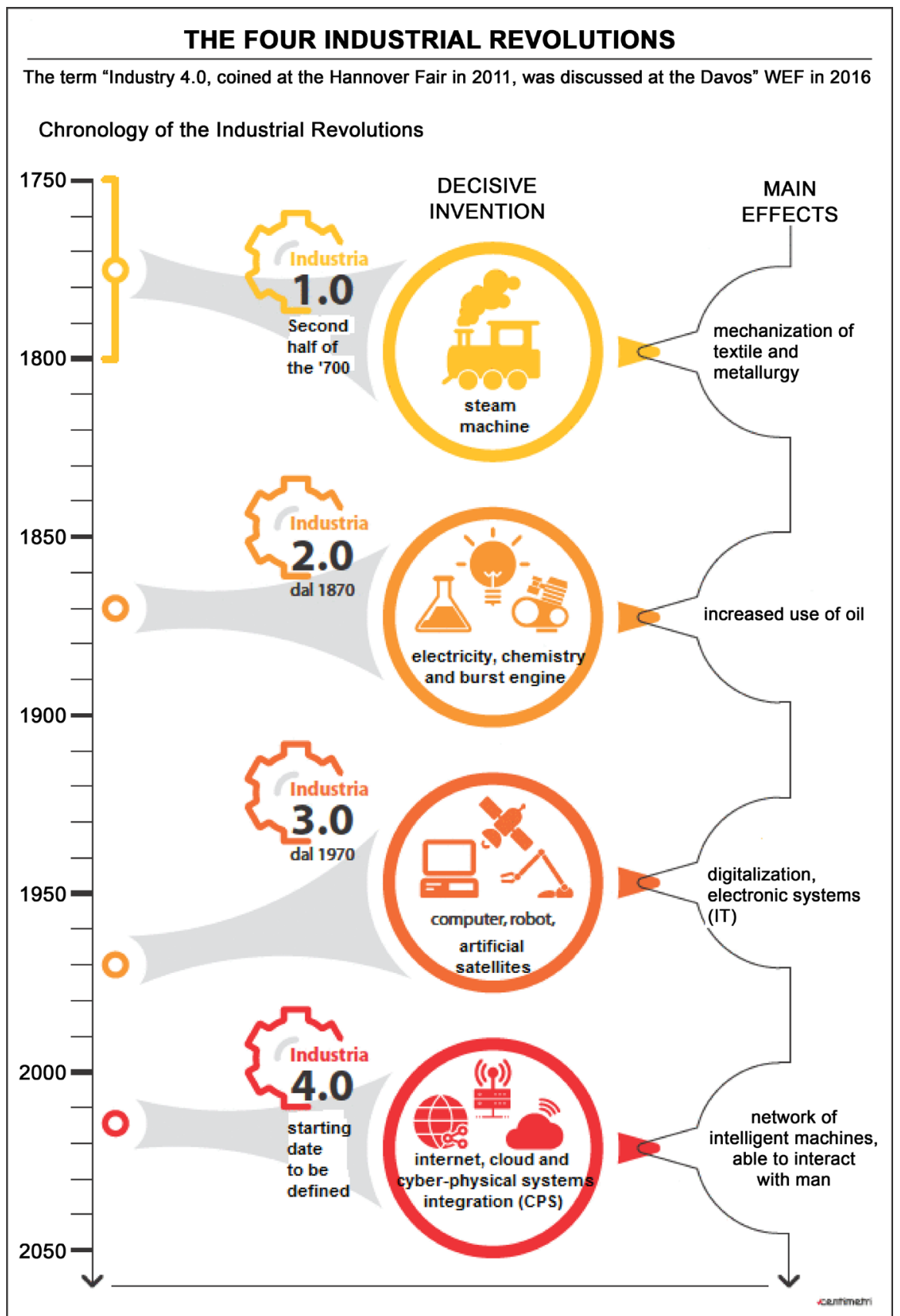

Image source (modified): http://www.borsaitaliana.it/notizie/sotto-la-lente/rivoluzione-252.htm.

Figure 1. The four Industrial Revolutions. During the second half of the $18^{\text {th }}$ century, England started an industrialization process that urged the Old and the New World to gradually abandon the mercantilist economic system, based on agriculture-crafts-trade, in favor of an industrial economic system, characterized by the extensive and intensive use of machines powered by mechanical energy and by the use of inanimate energy sources. The figure shows the chronology of the main breakthroughs that have accompanied the major transformations in the technological and scientific fields, from first to fourth Industrial Revolution.

unthinkable. This process will, in fact, be spread with different modes and speeds first across the Western European continent $\left(18^{\text {th }}\right.$ century/Industrial Rev- 
olution $1.0 \rightarrow 19^{\text {th }}$ century/Industrial Revolution 2.0) to be then exported and progressively adopted ( $19^{\text {th }}$ century/Industrial Revolution $2.0 \rightarrow 20^{\text {th }}$ century/ Industrial Revolution 3.0) by the European colonies of the New World, by Eastern European continent and by Japan, followed by China, the European colonies of Oceania, South Africa and South America, by Eastern Asia, the Middle East and finally, with the collapse of the Berlin Wall ( $20^{\text {th }}$ century/ Industrial Revolution $3.0 \rightarrow 20^{\text {th }}$ century/Industrial Revolution 4.0 ), by India and partly by North and Central Africa.

The centrality of mechanical systems in the industrial economic model, requires an adaptation of the human capital employed in the production chain, directly proportional to the needs imposed by the characteristics of the invested technological capital ${ }^{21}$. It is in this period that the process of integration between man and technology (mechanical systems) moves its first steps, assuming that human capital scarcely endowed with res cogitans (as the slaves deported from colonies and all non-white race, the women, children, and the male laborers), must exercise their own productive role in function of technological capital. As a consequence of this unavoidable prescription, a man-machine integration process takes shape which, in accordance with the postulates of the two souls of the Enlightenment, contemplates the idea of a humanity susceptible to corrections and adjustments, which can be induced either naturally or artificially, in order to make the anthropic characteristics and performance conform to the characteristics and performance of the mechanical systems.

The Industrial Revolution 2.0 (second half of the $19^{\text {th }}$ century) declines with the awareness that the man-machine integration process is not the only condition characterizing the process of industrialization. For this process to be effective, predictable and reproducible in the time and space of the Liberalism economic model (but also of the protectionist one, elaborated by historical materialism), it must be able to satisfy, and here the end justifies the means, at least three other conditions:

- adequate supply and exploitation of energy sources (supply must keep pace with increasing demand for energy, predominantly derived from fossil fuels, which is necessary to the functioning of mechanical systems; hence the definition of energy as the capacity of a body or system to do work).

- adequate supply and proper processing of raw materials (supply must keep pace with growing demand for materials required for the production of components of mechanical systems and their final products ${ }^{22}$ ).

\footnotetext{
${ }^{21}$ The bourgeois and scientific entrepreneurial pragmatism, reinterpreted collectively by the dialectical materialism of C. Marx and F. Engels, systematized the relationship between human capital (workforce) and technological capital (mechanical systems, technicians) in the so-called production cycle, which consists in the organization of work and profit regulated by a pyramid scale, where the easily replaceable human capital occupies the lowest step, and the hardly replaceable technological capital the highest.

${ }^{22}$ At present times United States, China and Russia are gearing up to plan the future exploitation (2050?) of rare raw materials on the Moon or on asteroids (e.g. helium-3, plagioclase, uranium, platinum, titanium, palladium, iridium), needed to power technological progress, but difficult or impossible (or destined to be exhausted) to find on our planet.
} 
- adequate research and implementation of new technical and technological solutions (adaptation of the offer to the request for expansion, diversification and optimization of the characteristics and performance of the mechanical systems; it is in this direction that, as from the first half of ' 900 , will strengthened the academicl industriall military iron triangle).

From and on these assumptions the Homo Technologicus ship is launched. Assaulted by the British port of the Industrial Revolution 1.0, with on board the first generation of solutions, corrections and adjustments (integrated by means of eugenics solutions and tools) of the anthropic characteristics and performance, depending on the characteristics and performance of the mechanical systems, the Homo Technologicus ship reaches us, at the globalized port of Industrial Revolution 4.0, in the Homo Artificialis version, with a load incredibly renewed, hyper-technological, sophisticated, futuristic, enhanced by solutions, corrections and adaptations supported by so-called Artificial Intelligence, by genetic manipulation ${ }^{23}$ and by digital mutation, which in the short and medium term promise to transform humans, by manipulating their germline lines $(\rightarrow$ CRISPR-Cas9) [15] [16] [17] [18] and by equipping them with internal and external electronic components (brain machines interfaces/brain computer interfaces) [19]-[27], in man-machine hybrid ( $\rightarrow$ cyborg), intended to support pseudo-intelligent or otherwise intelligent computerized mechanical systems, to which the status of electronic personalities ( $\rightarrow$ robots) is already legally recognized $^{24}$.

\title{
2. From Industrial Revolution 1.0 to Industrial Revolution 3.0: Historical Records
}

\author{
Capitalism is not only a better form of organizing human \\ activity than any deliberate design, any attempt to organize \\ it to satisfy particular preferences, to aim at what people regard \\ as beautiful or pleasant order, but it is also the indispensable \\ condition for just keeping that population alive which exists \\ already in the world. I regard the preservation of what is known \\ as the capitalist system, of the system of free markets and the \\ private ownership of the means of production, as an essential
}

\footnotetext{
${ }^{23}$ Today scientists are able to modify the germinal lines through a revolutionary genetic editing technique known as CRISPR-Cas9, a technique that, according to some, e.g. Robert Pollack (Department of Biological Sciences, Columbia University, New York) can open on the return of the eugenic program: the positive selection of the "right" (fit) versions of the human genome and the elimination of the "wrong" (unfit), not only for the health of an individual, but for the future of the species.

See: Pollack, R. (2015) Eugenics lurk in the shadow of CRISPR, Science, Vol. 348, Issue 6237, p. 871. http://www.columbia.edu/cu/biology/pdf-files/faculty/pollack/2015\%20Pollack\%20R.\%20_CRISPR \%20eugenics_\%20Science.pdf

${ }^{24}$ See: European Parliament resolution of 16 February 2017 with recommendations to the Commission on Civil Law Rules on Robotics (2015/2103(INL)).

http://www.europarl.europa.eu/sides/getDoc.do?pubRef=-//EP//TEXT+TA+P8-TA-2017-0051+0+D $\mathrm{OC}+\mathrm{XML}+\mathrm{V} 0 / / \mathrm{EN}$
} 
The political, social and economic systems of much of the contemporary world would not exist without the introduction of mechanical systems in production cycles. An epochal event that came to pass with the Industrial Revolution 1.0 (England, second half of the $18^{\text {th }}$ century, mechanization of production in the textile and metallurgical sector, invention of the steam engine) and that, as from the first half of the $19^{\text {th }}$ century, is governed by, and is variously subject to, the laws of the market, introduced by the financial oligarchies that control the stock systems (commodities and values), traditionally the London Stock Exchange (foundation year 1801) and the New York Stock Exchange (1817).

The epoch of the Industrial Revolution 1.0 has been distinguished from previous periods for the systematic introduction of inventions and technological innovations that gave the course to: a) a growing mechanization of production processes; $b$ ) the emergence of efficient and precise machine tools (such as the hydraulic chassis) and the design of machines powered by the steam force (making a steam engine economically and technically advantageous and efficient, was made possible by the use of the new blades built around 1775 by British John Wilkinson, initially used to produce cannon barrels, which allowed Watt to build with due precision the cylinders for his steam engines), resulting in increased labor productivity; $c$ ) the ability to manufacture standardized objects consisting of interchangeable parts; $d$ ) the ascent of coal as the predominant source of energy and $f$ ) the mechanization of transport (first half of the $19^{\text {th }}$ century, steamships and steam locomotives).

This acceleration in the pace of technological innovation did not affect the entire European territory in a homogeneous way. For about a century, the industrial revolution remained confined to England, Belgium, to a part of France, and to remote areas of Germany. Between the sixties and seventies of the $19^{\text {th }}$ century and the first decade of the $20^{\text {th }}$, industrialization expanded and intensified in Germany, Northern Italy, in some regions of the Austro-Hungarian Empire and Russian Empire, in Japan and United States. It is then that the new industrial urbanism values, the values of the civilized and industrious bourgeoisie, take the lead by building a different reference model and a new collective identity.

From the second half of the $19^{\text {th }}$ century (Industrial Revolution 2.0) the influence of scientific research on the evolution of the industry grew. The novelty of this period lies in the original alliance that is created between science, technology and industry. Scientific research is increasingly oriented towards its potential industrial applications and increasingly realized in the laboratories of large companies, which systematically apply the results to production, leading to the development of sectors that did not exist before, or that existed but with limited relevance, such as those of steel, electricity and chemistry. Unlike previous dec${ }^{25}$ As quoted in: Barness, J. (2011) Children of Liberty, Xlibris Corporation, p. 116. 
ades, inventors tend to have solid scientific training (they are mathematicians, engineers, biologists, chemists, physicists) and those of scientist, technician and researcher become highly specialized professions. These transformations were accompanied by others relating to the organization of production. The growth in investment and costs to be supported, increasingly less easily faced by family businesses, led to i) the affiliation of joint stock companies, ii) the dependence of many companies on bank credit, iii) the search for economies of scale, through the dimensional growth of companies, and iv) a policy of mergers and cartels, to limit competition and to integrate into a single corporate umbrella companies protagonists of the various stages of production of certain goods.

In many states, the school and university system experienced a functional evolution to meet the needs of the industry, which was expressing a growing demand for skilled workers.

It was the factory system the heart of what emerged progressively as the new organization of society and work. The large-scale application of technology to production, led increasingly to concentrate masses of workers in factories organized according to rational criteria, with functions, times, rhythms defined according to the needs of the division of labor. In this context, mechanization had a massive impact on capitalistic-led companies, starting from the textile, mining, steel and mechanical sectors, while, in parallel, the introduction of the steamship, of the first railway lines and telegraph, made it possible to build a new and very powerful network for the transport of goods and people and for communication.

For eugenists such as Margaret Sanger (1879-1966), founder of Planned Parenthood, the effects of the Industrial Revolution 2.0 were a threat, in response to which was invoked the planning and the use of special programs for birth control among the unfit.

This is what Sanger writes in this regard in her book The Pivot of Civilization, published in 1922 [28]:

The history of the industrial revolution and the dominance of all-conquering machinery in Western civilization show the inadequacy of political and economic measures to meet the terrific rise in population. The advent of the factory system, due especially to the development of machinery at the beginning of the nineteenth century, upset all the grandiloquent theories of the previous era. To meet the new situation created by the industrial revolution arose the new science of "political economy", or economics. Old political methods proved inadequate to keep pace with the problem presented by the rapid rise of the new machine and industrial power. The machine era very shortly and decisively exploded the simple belief that "all men are born free and equap". Political power was superseded by economic and industrial power. To sustain their supremacy in the political field, governments and politicians allied themselves to the new industrial oligarchy. Old political theories and practices were totally inadequate to control the new situation or to meet the complex problems that grew out of it. 
Just as the eighteenth century saw the rise and proliferation of political theories, the nineteenth witnessed the creation and development of the science of economics, which aimed to perfect an instrument for the study and analysis of an industrial society, and to offer a technique for the solution of the multifold problems it presented. But at the present moment, as the outcome of the machine era and competitive populations, the world has been thrown into a new situation, the solution of which is impossible solely by political or economic weapons.

The industrial revolution and the development of machinery in Europe and America called into being a new type of working-class. Machines were at first termed "labor-saving devices". In reality, as we now know, mechanical inventions and discoveries created unprecedented and increasingly enormous demand for "labor". The omnipresent and still existing scandal of child labor is ample evidence of this. Machine production in its opening phases, demanded large, concentrated and exploitable populations. Large production and the huge development of international trade through improved methods of transport, made possible the maintenance upon a low level of existence of these rapidly increasing proletarian populations. With the rise and spread throughout Europe and America of machine production, it is now possible to correlate the expansion of the "proletariat". The working-classes bred almost automatically to meet the demand for machine-serving "hands".

The rise in population, the multiplication of proletarian populations as a first result of mechanical industry, the appearance of great centers of population, the so-called urban drift, and the evils of overcrowding still remain insufficiently studied and stated. It is a significant though neglected fact that when, after long agitation in Great Britain, child labor was finally forbidden by law, the supply of children dropped appreciably. No longer of economic value in the factory, children were evidently a drug in the "home". Yet it is doubly significant that from this moment British labor began the long unending task of self-organization. Nineteenth century economics had no method of studying the interrelation of the biological factors with the industrial. Overcrowding, overwork, the progressive destruction of responsibility by the machine discipline, as is now perfectly obvious, had the most disastrous consequences upon human character and human habits. Paternalistic philanthropies and sentimental charities, which sprang up like mushrooms, only tended to increase the evils of indiscriminate breeding. From the physiological and psychological point of view, the factory system has been nothing less than catastrophic.

Dr. Austin Freeman has recently pointed out some of the physiological, psychological, and racial effects of machinery upon the proletariat, the breeders of the world. Speaking for Great Britain, Dr. Freeman suggests that the omnipresence of machinery tends toward the production of large but inferior populations. Evidences of biological and racial degeneracy are apparent to this observer. "Compared with the African negro", he writes, "the British sub-man is in several respects markedly inferior. He tends to be dull; he is usually quite help- 
less and unhandy, he has, as a rule, no skill or knowledge of handicraft, or indeed knowledge of any kind ... Over-population is a phenomenon connected with the survival of the unfit, and it is mechanism which has created conditions favorable to the survival of the unfit and the elimination of the fit". (...) One thing is certain. If machinery is detrimental to biological fitness, the machine must be destroyed, as it was in Samuel Butler's "Erewhon". But perhaps there is another way of mastering this problem.

(...) Birth Control which has been criticized as negative and destructive, is really the greatest and most truly eugenic method, and its adoption as part of the program of Eugenics would immediately give a concrete and realistic power to that science. As a matter of fact, Birth Control has been accepted by most clear thinking and far seeing of the Eugenists themselves as the most constructive and necessary of the means to racial health.

The first half of the $20^{\text {th }}$ century was marked by the accentuation in all industrialized countries of the protectionist and leadership policies emerged over the previous century. This tendency manifested itself in the epochs of the two world conflicts (in which the states were forced to seek self-sufficiency in the various production sectors and to submit industrial activity to strict control, in order to make it functional to the war effort). In the first decades of the century, scientific-technological progress favored, as it had already done in the late $19^{\text {th }}$ century, the progress of existing industrial sectors and the emergence of new compartments. In particular, there was a large increase in electricity consumption, the diffusion of new means of communication (telephone and radio), a growing mechanization of agriculture and the development of aviation and the automotive industry.

From World War II, European countries emerged greatly weakened industrially, due to war breaks, shortages of financial resources, and to disruption of trade relations with other continents, while the US came out stronger, not only because their apparatus production had not suffered direct damage, but also because the strong military demand had stimulated its expansion and modernization.

In this post-war international scenario, the American academiclindustriall military iron triangle gains the unquestioned power to drive the process of industrialization on a global scale and decide on the fate of the man-machine integration process. The propulsive action imprinted on both processes by the exercise of the US knowledge and know-how, becomes the determining and characterizing factor of the transition from second to third and from third to fourth, industrial revolution.

\section{Progressive Techno-Scientism: from Eugenics to Artificial Intelligence}

[Eugenics] must be introduced into the national conscience, like a new religion. It has, indeed, strong claims to become an orthodox religious tenet of the future, for eugenics co-operate with 
the workings of nature by securing that humanity shall be represented by the fittest races. What nature does blindly, slowly, and ruthlessly, man may do providently, quickly, and kindly.

Francis Galton ${ }^{26}$

The emergence of Positivist thought goes hand in hand with the transition from the first to the second industrial revolution.

Thanks to the action exercised by the two souls of the Enlightenment, Naturophilus and Technophilus, on the man-machine integration process 2.0, and under the suggestions offered by Darwinian theory of evolution, the bourgeois European class of the second half of the $19^{\text {th }}$ century did not interprets anymore reality according to the traditional metaphysical categories of immutability and necessity, of innativeness and of fixity, but rather of dynamism and progress (scientific, technological and industrial).

Evolutionism, the new $19^{\text {th }}$ century dogma of the metaphysics applied for practical purposes, describes the movement of history and, above all, interprets this universal movement in a finalistic way, that is, as directed to a positive approach, the condition of universal happiness, assimilating in this sense the progressive conception of history introduced by the Jewish-Christian promise of the Kingdom of Heaven, then reinterpreted in a materialistic way by Enlightenment.

In this context, both cultural and social, takes shape the current of thought that we call progressive techno-scientism.

On a cultural level, progressive techno-scientism radicalizes the motives of convergence between scientism (France, second half of $19^{\text {th }}$ century) and $s o$ cial-Darwinism (England, second half of $19^{\text {th }}$ century), between faith in the power of science as metaphysics of indisputable-absolute certainties and technology as a tangible proof of its effectiveness, and the conviction that the linear, progressive and ascending evolution applied by Darwin to biological systems can also be applied to social systems (social Darwinism $\rightarrow$ Herbert Spencer): reality expresses a universal development, constant, progressive and necessary, towards more and more evolved forms of life, from simple to complex, from homogeneous to heterogeneous, from inferior to superior. On the social level, progressive techno-scientism fully welcomes the most radical instances, in the smell of conquering and racist colonial messianism, expressed by the bourgeois Enlighteners class: $i$ ) the bourgeoisie has the full power to claim and pursue the right-duty to civilize peoples and individuals judged inferior for their cultures or their development (Figure 2) so that every nation one day arrive at the state of civilization attained by those people who are most enlightened, most free, most exempt from prejudices, as the French, for instance, and the Anglo-Americans (Condorcet); ii) the bourgeoisie has the full power to claim and to pursue the right-duty to

${ }^{26}$ Galton, F. (1904) Eugenics: its definition, Scope, And Aims, The American Journal Of Sociology, Volume X, Number 1.

http://galton.org/essays/1900-1911/galton-1904-am-journ-soc-eugenics-scope-aims.htm 


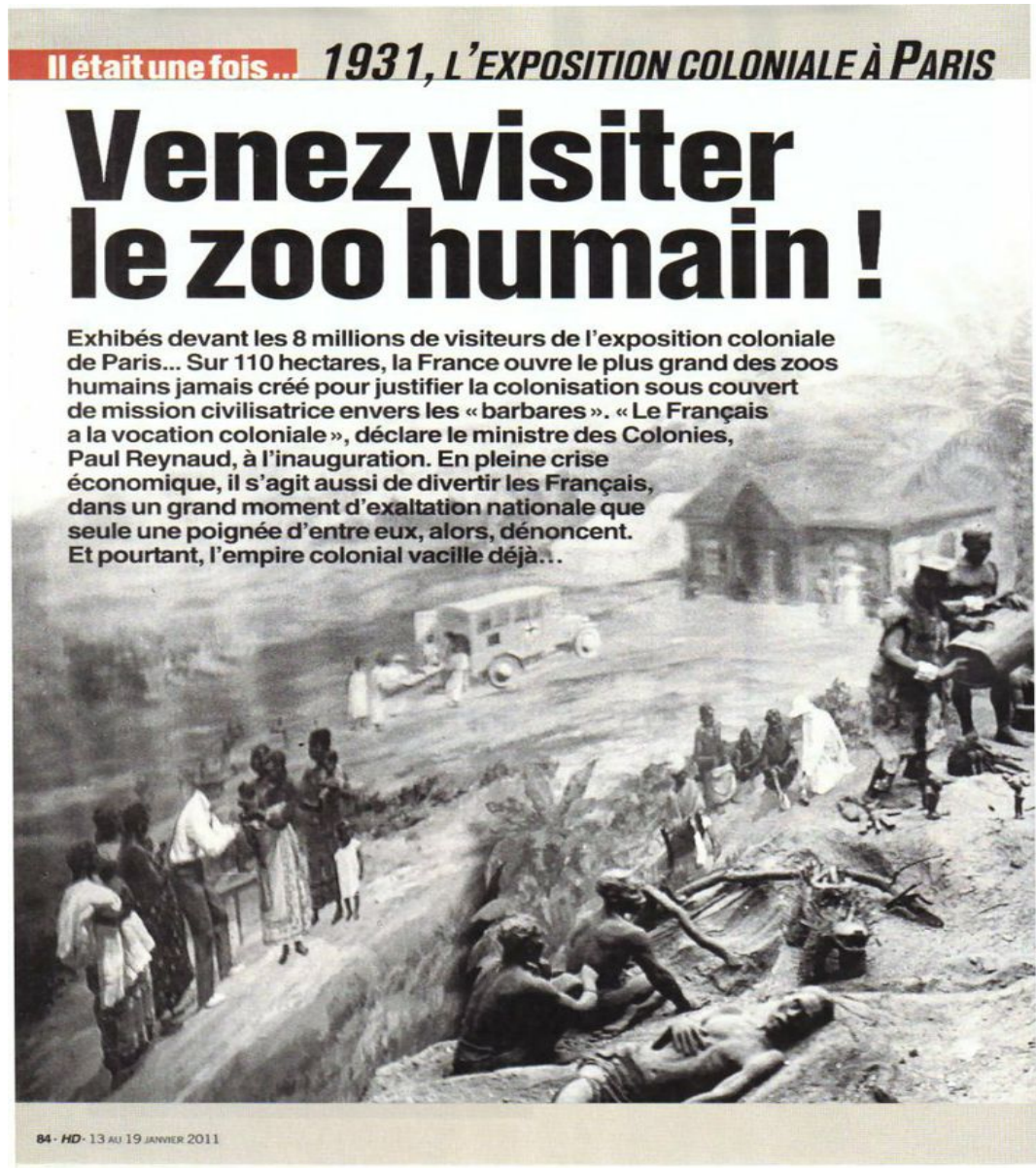

Image source:

https://gherkinstomatoes.com/2011/06/30/eating-around-the-empire-in-a-day-the-1931-paris-intern ational-colonial-exposition/

Figure 2. Parisian world fair 1931. Human zoos were 19th and 20th century public exhibits of people like museum pieces (also known as "an ethnological exposition", "the exhibition of human beings" and "a Negro Village")—-mostly non-Europeans. Africans, Asians, Indigenous people and many others were often caged and displayed in a makeshift 'natural habitat'. Human zoos and exhibitions of exotic populations became common in the 1870 's in the midst of the New Imperialism period. They could be found in many places including Hamburg, Antwerp, Barcelona, London, Milan, New York, Warsaw, St. Louis and New York City and hundreds of thousands of people visited these exhibitions. Such zoos, especially in Germany, had strongly pronounced racist implication, which was taken from the Social Darwinism currents, when people from Africa were often demonstrated together with monkeys in order to show their common origin.

improve mankind through a progressive selection and/or modification and/or integration and/or substitution, natural and/or artificial, of the human being, following the criteria dictated by scientific progress (science and technology, by virtue of the effectiveness of their means, can transform what was naturally predetermined).

Eugenics and Artificial Intelligence represent respectively the first and last ideological Manifesto of the unlimited human perfectibility project undertaken by progressive techno-scientism. 


\title{
3.1. Progressive Techno-Scientism and Eugenics Thought
}

\author{
I propose that 100,000 degenerate Britons should be \\ forcibly sterilized and others put in labour camps to \\ halt the decline of the British race.
}

Winston Churchill ${ }^{27}$

The Eugenics thought, is the speech, from the Naturophilous/conservationist and Tecnophilous/mechanistic point of view, on why the Caucasian race (John Friederich Blumenbach, 1865) is superior to the other races and how this self-referential and pseudo-scientific primacy must be safeguarded.

A school of thought that seems to satisfy the positivists and neo-positivists need, already clearly expressed by Auguste Comte ${ }^{28}$, to find a scientific substitute for clerical orthodoxy (Adam Cohen defines Eugenics as a sort of secular religion [29]), able to concretely fulfill the dream of a scientific unlimited human perfectibility project. A dream where order and happiness are guaranteed on a bio-psychic basis by segregation, reification, elimination of the unfit, the inferiors (dysgenics), and by the racial, meritocratic (now back in fashion under the influence of neo-liberalist globalization) and gender exploitation of the fit, the superiors (eugenics).

The conservationist current of Eugenics thought was born out of the Positivist elaboration of the Enlightenment Naturophilus soul, in the name of the evolutionary biology, in order to plan the suppression of the unfit and the control of their reproduction and diffusion with strategies and methods considered natural, a position that the English economist Thomas Robert Malthus (1766-1834) anticipated well with these words ${ }^{29}$ : All the children born, beyond what would be required to keep up the population to this level, must necessarily perish, unless room be made for them by the deaths of grown persons. (...) To act consistently therefore, we should facilitate, instead of foolishly and vainly endeavouring to impede, the operations of nature in producing this mortality, and if we dread the too frequent visitation of the horrid form of famine, we should sedulously encourage the other forms of destruction, which we compel nature to use. Instead of recommending cleanliness to the poor, we should encourage contrary habits. In our towns we should make the streets narrower, crowd more people into the

\footnotetext{
${ }^{27}$ As Home Secretary in a 1910 Departmental Paper. The original document is in the collection of Asquith's papers at the Bodleian Library in Oxford. Also quoted in Clive Ponting, "Churchill" (Sinclair Stevenson 1994).

${ }^{28}$ In the last years of his life Auguste Comte (1798-1857), ideologue of positivism, writes the Positivist Catechism and establishes the Positivist Church, where the doctrinal, ethical and liturgical elements of Catholic tradition are transposed.

${ }^{29}$ Malthus, T.R. (1826) An Essay on the Principle of Population. Or a View of Its Past and Present Effects on Human Happiness; with an Inquiry Into Our Prospects Respecting the Future Removal or Mitigation of the Evils which It Occasions. Book IV, Chapter V, Of the Consequences of pursuing the opposite Mode, IV.V.1, Library of Economics and Liberty. Retrieved June 17, 2017 from the World Wide Web: http://www.econlib.org/library/Malthus/malPlong30.html\#dd12
} 
houses, and court the return of the plague. In the country, we should build our villages near stagnant pools, and particularly encourage settlements in all marshy and unwholesome situations. But above all, we should reprobate specific remedies for ravaging diseases; and those benevolent, but much mistaken men, who have thought they were doing a service to mankind by projecting schemes for the total extirpation of particular disorders.

The mechanistic current was born out of the Positivist elaboration of the Enlightenment Technophilus soul, in the name of the deterministic conception expressed by the mathematician and astronomer Pierre-Simon de Laplace in his Systeme du monde (1814), to promote the unlimited scientific refinement, with artificial strategies and methods, of the human species, i.e. its progressive homologation to "the state of civilization attained by those people who are most enlightened, most free, most exempt from prejudices, as the French, for instance, and the Anglo-Americans" (Condorcet). As previously stated by Condorcet: In sine, may it not be expected that the human race will be ameliorated by new discoveries in the sciences and the arts, and, as an unavoidable consequence, in the means of individual and general prosperity, by farther progress in the principles of conduct, and in moral practice, and lastly, by the real improvement of our faculties, moral, intellectual and physical, which may be the result either of the improvement of the instruments which increase the power and direct the exercise of those faculties, or of the improvement of our natural organization itself? (....) And who shall presume to foretel to what perfection the art of converting the elements of life into substances sitted for our use, may, in a progression of ages, be brought? But supposing the affirmative, supposing it actually to take place, there would result from it nothing alarming, either to the happiness of the human race, or its indefinite perfectibility (...) Would it even be absurd to suppose this quality of melioration in the human species as susceptible of an indefinite advancement, to suppose that a period must one day arrive when death will be nothing more than the effect either of extraordinary accidents, or of the slow and gradual decay of the vital powers, and that the duration of the middle space, of the interval between the birth of man and this decay, will itself have no assignable limit? Certainly man will not become immortal; but may not the distance between the moment in which he draws his first breath, and the common term when, in the course of nature, without malady or accident, he finds it impossible any longer to exist, be necessarily protracted?

Neologism Eugenics [30] is coined in the early eighties of the $19^{\text {th }}$ century by the English anthropologist, statist, psychologist, explorer Francis Galton ${ }^{30}$ (1822-1911), Charles Darwin's first cousin, and assigned to a system of thought which theorized, with scientific arguments extracted from the new born Mendelian theory (of the transmission mode of hereditary characters) and from the

\footnotetext{
${ }^{30}$ Francis Galton was a pioneer in scientific disciplines such as biometrics (he developed the basic techniques and principles for fingerprinting), meteorology (he discovered anticyclon), statistics (he made the first studies on multifactorial correlation) and experimental psychology (he developed the first mental tests).
} 
new born Darwinian theory (of the linear, progressive and ascending evolution of biological systems), the progressive improvement of race (biological racism ${ }^{31}$ ) and the supposed intellective superiority of Europeans male, white, acculturated and well-off compared to the other racial groups (including lower-rated social groups, such as white adults of disadvantaged social groups and women, who were equated, for anatomical and mental characteristics, to the white children male of the cults considered superior, and presented in a Darwinian key as living specimens of primitive phases of the linear, progressive and ascending evolution of the latter).

Concepts such as evolution and adaptation are used by Galton to legitimize the leadership of the rich bourgeoisie of industry and commerce, which had made the British nation great in the international scenario and in the cultural relations between races $^{32}$. The very concept of natural selection (natural selection chooses among the possible emerging random variation between individuals of a species, the more favorable for survival, and therefore for the breeding in a particular environment, ensuring the survival of the only individuals best suited in the struggle for life and death) is used ideologically and conservatively as a criterion of distinction between fit and unfit, although it is already decided upon the criteria for identifying the fit, how to establish the distinctive features, in relation to whom or what.

Among the sixties of the $19^{\text {th }}$ century and the sixties of the $20^{\text {th }}$ century, Eugenic policies extended to Europeans judged unfit, the same dehumanizing treatment, now corroborated by pseudo-scientific theses, that European colonists had for centuries reserved to colonized peoples ${ }^{33}$. The Eugenics ideas spread from Sweden to Russia to England to Portugal to Germany to Italy to Denmark to Japan to France to the United States of America to South America to Oceania to Africa and to various European colonies scattered around the planet. Racial hygiene practices became part of the collective and institutional behavioral norms intended to improve the race, legitimating an uninterrupted series of crimes against the person and against humanity:

- selective breeding by coercive selection or modification of germinal lines $(\rightarrow$

\footnotetext{
${ }^{31}$ Biological racism was consolidated starting from the first half of the $18^{\text {th }}$ century thanks to the first anthropological classification of races. Carl von Linné (1707-1778) and Georges-Louis Leclerc, Comte de Buffon (1707-1788) introduced Taxonomy and subdivided peoples according to the skin color, size and shape of the body, claiming that phenotypic similarities were in fact the race.

${ }^{32}$ Between the $16^{\text {th }}$ and $17^{\text {th }}$ century, the expansion of commercial routes to the Americas, Africa, the Indies and the Far East, and the consolidation of the British primacy on the seas, conquered at the expense of the naval fleets of France, Spain, Portugal and the Netherlands, and encouraged by progressive metallurgical improvements in the construction of cannons and the use of gunpowder, allowed the European aristocracies, and in particular English, to enrich themselves by importing large quantities of raw materials, precious metals and other merchandise (including slaves), exporting overseas, this yes, the conquistadores' ferocity, forced evangelization of unbelievers, alcohol, smallpox, gonorrhea, plague and other calamities that flagged entire generations of inferior races.

${ }^{33}$ In the $16^{\text {th }}$ century conquistador J. Ginés de Sepúlveda distinguished men (spanish) from homunculi (indios), similar to humans, but in fact inferior and animal-like, so worthy of being treated as animals.
} 
forced mass sterilization ${ }^{34}$; forced coupling between individuals according to traditional techniques for livestock breeding, including hybridization);

- forced separation and removal of the offspring from the unfit families, to become human material for use and consumption of the fit;

- systematic application of the law of the strongest, evoked and justified by a supposed general law of nature, expressing itself in the struggle for life and death, and legitimizing, on the biological-anthropological level, the disparities between humans and the elimination of the weakness ( $\rightarrow$ slavery, racial segregation, summary elimination or reduction to the impotence of anyone obstructing or polluting the path of the fit);

- medical experimentation on human guinea pigs (tens of thousands of individuals considered unsuitable or unfit or simply useless and harmful were locked up in psychiatric institutions, or in special colonies for unfit, and subjected to electroshock, genital mutilation, frontal lobotomy and other restrictive and medical-surgical practices that will be emulated and applied on a large scale by, among others, the Nazi-fascists, the Stalinists and the Japanese Empire Army).

\subsection{The Eugenics Cause and the Academic/Industrial/Military Iron Triangle}

A part of eugenic politics would finally land us in an extensive use of the lethal chamber. A great many people would have to be put out of existence simply because it wastes other people's time to look after them.

George Bernard Shaw ${ }^{35}$

Between the end of $19^{\text {th }}$ century and Second World War, the Eugenics cause caused many acolytes, ordinary people, politicians, lawmakers, esteemed scientists, accredited researchers, entrepreneurs, wealthy businessmen, illustrious psychologists, economists, religious, sociologists, anthropologists [31]. Making it a complete list would be impossible and superfluous, because consensus towards it was not the exception but the rule ${ }^{36}$.

${ }^{34}$ During the $20^{\text {th }}$ century, the institutionalization of coat sterilization programs involved thousands of people who were considered unfit for procreation. In the United States these programs lasted from 1907 to 1973 and involved 27 states over 50; in Canada from 1928 to 1972; in Switzerland from 1928 to 1985; in Denmark from 1929 to 1967; in Germany from 1933 to 1945; in Norway from 1934 to 1977; in Sweden from 1935 to 1976; in Finland from 1935 to 1970; in Japan from 1949 to 1994; in France from 1950 to 1980.

${ }^{35}$ George Bernard Shaw, Lecture to the Eugenics Education Society, Reported in The Daily Express, March 4, 1910.

${ }^{36}$ Care for the race, even if the individual must suffer-this must be the keynote of our future. This was the guiding principle which underlay all the discussions of the Second International Congress ot Eugenics in 1921. Not quantity but quality must be the aim in the development of each nation, to make men fit to maintain their places in the struggle for existence. We must be concerned above ali with racial values; every race must seek out and develop and improve its own racial characteristics. Racial consciousness is not pride of race, but proper respect for the Purity of race is today found in but one nation-the Scandinavian. [Henry Fairfiled Obsborn (1857-1935)] 
However, for the purpose of this paper, it is useful to mention at least some of the many significant intersections (which tend to survive at the departure of their actors) between the academic, industrial and military world, i.e. the academic/industrial/military iron triangle, in particular in the United States of America [32] [33] [34], before World War II, in support of the Eugenics cause.

Here are some.

Between the ' $20^{\mathrm{s}}$ and ' $40^{\mathrm{s}}$ of $20^{\text {th }}$ century some American investors, Dutch bankers and German businessmen gave birth to a millionaire turnover, the New York-Rotterdam-Berlin Connection, which funded the rise to power by Adolf Hitler, continuing to do business with the Third Reich throughout World War II [35]. The players of this business venture were: the German family of Thyssen (steel magnates); the US investment company W.A. Harriman \& Co., based in New York City, founded in 1920 (owned by the Harriman family and managed by Averell Harriman, son of E. H. Harriman, American railroad magnate, and Edward Roland Harriman, the second son); the August Thyssen Bank, headquartered in Berlin, owned by the Thyssen family; the Dutch Bank voor Handel en Scheepvaart, headquartered in Rotterdam, controlled by the Thyssen family; the American Union Banking Corporation (UBC, based in New York City, in the same building as W.A. Harriman \& Co.), founded in 1924 and controlled by the Thyssen family and the Harriman family; the German family of Flick (entrepreneurs in the coal and steel sector); the Bush family, in the person of Prescot Bush (George H. W. Bush's father, future president of the United States of America) appointed vice-president of W.A. Harriman \& Co. in 1926; the United Steel Works (USW), founded in 1926 by the American investment firm Dillon Read Co., owned by Clarence Dillon, and Fritz Thyssen, who became Hitler's largest lender; and finally, the various customers of W.A. Harriman \& Co., among which stands the Rockefeller family, who through the companies of the Thyssen family made gold deals with Nazi Germany.

The Eugenics Record Office (ERO) was a Research Institute dedicated to eugenics and human inheritance studies. It was founded in 1910 by Charles B. Davenport and Harry H. Laughlin (two of the major advocates and speakers of Eugenics in USA), thanks to funds provided by the wealthy widow Mary Harriman (EH Harriman's wife), John Harvey Kellogg (the cereal magnate who founded the Kellogg Race Betterment Foundation in 1911) and the Carnegie Institution of Washington's Station for Experimental Evolution, founded in 1902 by millionaire Andrew Carnegie (steel magnate) [36]. In 1904, Davenport, under the auspices of the Carnegie Institution of Washington, launched the American Eugenics movement in the form of an alliance between companies, Protestant churches, the American intelligentsia and most of the American geneticists favorable to address the problems of social disfunction, by means of selection procedures for the psychological traits associated with race and social class.

The American Breeders' Association, founded in 1903, was the first scientific organization in the United States to recognize the importance of Mendel's laws 
and to support eugenic research (through a subcommittee chaired by ichthyologist and Stanford University's president David Starr Jordan), in 1914 changed its name to the American Genetic Association (AGA) [37], the current denomination.

The exclusive Boone and Crockett Club (B \& C, founding year 1887) was the first and most authoritative American conservationist association, engaged in the field of Eugenics and immigration restrictions. Among its members, largely naturalists, appear Theodor Roosevelt (founder of the Club and 26th President of the United States), Madison Grant [38], author of the book The Passing of the Great Race ("a torrid work of racial alarmism and pseudo-science that Adolf Hitler called 'my bible' in an admiring letter to Grant" [39]), and Ghifford Pinchot, a fierce supporter of the purity of the Anglo-Saxon race, delegated to the first (1912) and second (1921) Eugenic International Congress and member of the Advisory Council of the American Eugenics Society from 1925 to 1935.

The Rockefeller Foundation (RF) funded various projects for the promotion and application of Eugenics thinking both in the United States and abroad [40] [41] [42] [43]: "Attitude" was a key word in the Rockefeller vocabulary: finding individuals and institutions that shared their ideals and could be trusted to translate grants into tangible results [44]. Among these are the racial hygiene projects conducted by the Kaiser Wilhelm Institute for Psychiatry in Munich (started in 1918), directed from 1928 (when the Rockefeller Foundation donated to the Institute $\$ 325,000$ for the construction of a new building [45]), by the psychiatrist and member of the German Nazi party Ernst Rüdin, and those conducted by Berlin's Kaiser Wilhelm Institute for Anthropology, Human Heredity and Eugenics (1927), directed (from 1927 to 1942) by Eugen Fischer, anthropologist, member of the German Nazi Party. RF also funded the construction and organization of the School of Public Health in Zagreb ${ }^{37}$. Several Eugenetists were funded by RF, including the Germans Heinrich Poll [46] and Alfred Grotjahn [47], a socialist, fierce racial health supporter and mentor of another German Eugenetist, George Wolff, who emigrated to the United States (1937) where he exported Grotjahn's racial doctrine [48], and where he had a brilliant career that in 1952 saw him at the command of the Biometrics Branch of the Civil Aeronautics Administration.

Illustrious Eugenists were, among others, Alexander Graham Bell (18471922), inventor of the phone, honorary president of the 2nd Eugenic International Congress in 1921.

Robert Mearns Yerkes (1876-1956), psychologist, was commissioned by the American Psychological Association, under the mandate of the US Department

\footnotetext{
37"Rockefeller foundation was financing German eugenists Poll and Grotjahn, as well as main eugenics institutes in Germany, such as Kaiser Wilhelm Institute for Psychiatry and Kaiser Wilhelm Institute for Anthropology, Eugenics, and Human Inheritance. The same foundation financially supported the construction and organization of the Zagreb School of Public Health". In: FatovićFerencić, S. (2008) "Society as an Organism:” Metaphor as Departure Point of Andrija Štampar's Health Ideology, Croatian Medical Journal, Dec; 49(6): 709-719.

https://www.ncbi.nlm.nih.gov/pmc/articles/PMC2621036/
} 
of Defense, to chair the Committee on the Psychological Examination of Recruits, a team of 40 psychologists, among which stands out the figure of another pioneer in the IQ test, the psychologist Henry Herbert Goddard (1866-1957), who developed, in line with Eugenics thinking, two IQ tests, the Army Alpha and Beta test, which were administered at 1.75 million recruits of the US Army, paving the way for large-scale IQ testing at school as well (the IQ Test Sponsor, the National Research Council Psychology Committee, also chaired by Yerkes, described the IQ test administered in schools as "the application of the army testing methods to school needs" [49].

Nobel Prize winner James Watson, US biologist and discoverer, together with Francis Crick, Maurice Wilkins and Rosalind Franklin, of the molecular structure of DNA (1952), in an interview in 2014 stated that: "Eugenics is sort of self correcting your evolution, and the message I have is that individuals should direct the evolution of their descendants, don't let the State do it. I think it would be irresponsible not to direct your evolution if you could, in the sense that you could have a healthy child versus an unhealthy child, I think it is irresponsible not to try and direct the evolution to produce a human being who would be an asset to the world as well as to himself ${ }^{\beta 8}$.

Karl Pearson (1857-1936), English mathematician, president of the Galton Eugenics Laboratory (created by Francis Galton in 1907, from the merger of the Biometric Laboratory directed by Pearson and Galton's Eugenics Record Office), headquartered in the University College of London.

Sir George Darwin and Leonard Darwin, the latter president of the British Eugenics George Bernard Shaw (1856-1950), Nobel Prize for Literature in 1925, Stalin's supporter and friend, wrote ${ }^{39}$ : The moment we face it frankly we are driven to the conclusion that the community has a right to put a price on the right to live in it. If people are fit to live, let them live under decent human conditions. If they are not fit to live, kill them in a decent human way. Is it any wonder that some of us are driven to prescribe the lethal chamber as the solution for the hard cases which are at present made the excuse for dragging all the other cases down to their level, and the only solution that will create a sense of full social responsibility in modern populations?

Winston Churchill (1874-1965), was Home Secretary at Eugenic Education Society from 1910 to 1911 (founded in 1907, changed name to the British Eugenics Society in 1926 and later to the Galton Institute in 1989, the current denomination); in 1911, when he was a military navy minister, he attended the presidency (along with Lord Alverstone, then Minister of Justice, Charles Eliot, President of Harvard University and Alexander Bell) of the first Eugenetic World Congress, organized by the University of Oxford. British Prime Minister

\footnotetext{
${ }^{38}$ Interview: James Watson talks about eugenics and bioethics. https://www.dnalc.org/view/15472-Eugenics-and-bioethics-James-Watson.html

${ }^{39}$ As quoted in: Conroy, M. (2017) Nazi Eugenics: Precursors, Policy, Aftermath, Columbia University Press. Originally from George Bernard Shaw, Prefaces, Constable and Co., London, 1934, p. 296.
} 
from 1944 to 1945 and again from 1951 to 1955, Nobel Prize in Literature in 1953, was among the first editors of the Mental Deficiency Act ${ }^{0}$ (1913). In October 1910 a deputation to the Government called for the implementation of the Royal Commission's recommendations without delay. Churchill, in his reply ${ }^{41}$, recalled the fact that there were at least 120,000 "feeble-minded" persons "at large in our midst" who deserved "all that could be done for them by a Christian and scientific civilization now that they are in the world", but who should, if possible, be "segregated under proper conditions so that their curse died with them and was not transmitted to future generations" ${ }^{\prime 2}$.

In 1935 the French surgeon and biologist Alexis Carrel, a Nobel prize winner on the staff of the Rockefeller Institute, publishes Man the Unknown. He proposes disposing of criminals and people who are mentally ill via euthanasia institutions equipped with suitable gases. In 1939 Hitler orders widespread 'mercy killing' of sick and disabled people. The Nazi euthanasia program, to eliminate 'life unworthy of life,' is code-named Aktion T4 (acronym that stood for the Berlin villa located at civic 4 in Tiergartenstrasse). An estimated 275,000 people are killed under the programme from 1939 to $1945^{43}$.

Many have wondered how it has been possible that Western civilization that originated from the Age of Reason could have given birth to such fierce devastation and inhuman suffering. Perhaps the answer is in the words of Denis Diderot: The most dangerous madmen are those created by religion, and ... People whose aim is to disrupt society always know how to make good use of them on occasion [Conversation with a Christian Lady (1774)].

\footnotetext{
${ }^{40}$ The Mental Deficiency Act categorises people with learning disabilities and mental health issues as 'idiots' (those so deeply defective as to be unable to guard themselves against common physical dangers), 'imbeciles' (whose defectiveness does not amount to idiocy, but is so pronounced that they are incapable of managing themselves or their affairs, or, in the case of children, of being taught to do so), 'feeble-minded' (whose weakness does not amount to imbecility, yet who require care, supervision, or control, for their protection or for the protection of others, or, in the case of children, are incapable of receiving benefit from the instruction in ordinary schools) or 'moral defectives' (displaying mental weakness coupled with strong vicious or criminal propensities, and on whom punishment has little or no deterrent effect). Gradually, unmarried mothers begin to be placed in this 'moral defective' category too. Many people acquire their diagnosis of mental deficiency because of extreme childhood adversity or institutional care. The Act leads to many more people with learning difficulties being segregated.

${ }^{41}$ As quoted by Sir Martin Gilbert CBE, in Churchill and Eugenics. https://www.winstonchurchill.org/publications/finest-hour-extras/churchill-and-eugenics-1

${ }^{42}$ There are 120,000 or 130,000 feeble minded persons at large in our midst. These unhappy beings deserve our care and assistance, and deserve all that could be done for them, now that they are in the world, by a Christian and scientific civilisation. But let it end there if possible. If we were able to segregate these people under proper conditions, so that their curse died with them and was not transmitted to future generations, we should have taken up our shoulders in our own lifetime a work ot which those who came after us would owe us a debt of gratitude". [Winston Churchill, as reported by The Times, $15^{\text {th }}$ July 1910]

${ }^{43}$ Nevertheless, a eugenist the caliber of James Watson believes that: "Here we must not fall into the absurd trap of being against everything Hitler was for ... Because of Hitler's use of the term Master Race, we should not feel the need to say that we never want to use genetics to make humans more capable than they are today." [Watson, J. (2000) A Passion for DNA: Genes, Genomes, and Society, Cold Spring Harbor Laboratory Press]
} 
Enlightenment has given rise to a (monotheist) secular religion ${ }^{44}$ [50] [51] [52] [53] (which, being an oxymoron, is humus for individual and collective schizophrenic disorders): “... what the Enlightenment thought failed to see, dazzled as it was from the light of modern reason, it is how deeply rooted in the human psyche is the symbolism, and how imperative is the need for any human community to rely on transcendent and founder otherness" [54] [my translation].

Positivism has consecrated it on the altar of the newborn academic/industriall military iron triangle.

Eugenists established the Inquisition courts of the Positivist Church.

Men like Hitler, Mussolini and Stalin used it to put the nation at the service of their delirium of omnipotence.

Men like Winston Churchill used it to put their power ambitions at the service of the nation: The religion of blood and war [Mahommedan] is face to face with that of peace [Christianity]. Luckily the religion of peace is usually the better armed. [Winston Churchill, The Story of the Malakand Field Force: An Episode of Frontier War (1898)]

What can we expect from the present preachers, with transumanists on the forefront, of the hyper-technological perfectibility of humanity?

\section{Progressive Techno-Scientism 4.0: Towards the Robotization of Society}

That is to say, if we humans are simply parts of systems - our skins not boundaries but permeable membranes, our actions measured as behavior rather than by introspection the autonomous, sufficient "self" begins to seem an illusion. $N W F^{45}$

For the academic/industrial/military iron triangle, two world wars, racial hygiene programs, chemical and bacteriological weapons, the development of ground, air and sea weapons, the use of nuclear weapons on Hiroshima and Nagasaki and millions of civilian casualties, represented an opportunity to develop

\footnotetext{
${ }^{44}$ In The Future of Secular Religions (1944), Raymond Aron had defined secular religions: "those doctrines that, in the soul of our contemporaries, take the place of the lost faith, and that place the salvation of humanity in this world, in a distant future, in the form of a social order to be built' [my translation of the French version quoted in: Maier. H. (edited by) (2008) Totalitarianism and Political Religions Volume III: Concepts for the Comparison Of Dictatorships - Theory \& History of Interpretations, Routledge, p. 160]. In Sociology of Communism (1949), Jules Monnerot describes a secular religion as follows: "When a whole series of events, of peoples, of ideas escapes critics, this means that a sacred area is opposed to that dominated by the profane: in this case it can be talked about a religious phenomenon. Such is the secular religion (and such is the totalitarian state: the two phenomena are connected) characterized by the active presence of a faith, myths, and dogmas". [my translation of the French version quoted in: Ellul, J. (2008) La technique ou l'enjeu du siécle. Economica Paris, p. 335]

${ }^{45}$ From the introduction to "Men, Machines, and the World About", Norbert Wiener, by the Institute of Electrical and Electronics Engineers (IEEE).

http://21stcenturywiener.org/wp-content/uploads/2013/11/Men-Machines-and-the-World-About-b y-N.-Wiener.pdf
} 
persuasive and dissuasive strategies and techniques and technological solutions that have had enormous repercussions both on the future of the military and the civilian sector.

An opportunity that has not been reversed even in the face of the possibility of acquiring information of scientific interest, with criminal methods conducted on human guinea pigs with unprecedented cruelty. Like those that distinguish the story page (1936-1945) written by Unit 731 [55] [56] [57].

Set up by the Japanese army in 1936 at Ping Han, near Harbin, Manchukuo's puppet state, Unit 731 was a military research center entrusted to the command of a graduate in medicine, Shiro Ishii, where doctors and other Japanese graduate live-dissected, infected with bacteriological agents, subjected to transplants, mutilations and other torture conceived as experiments over three thousand subjects considered fit to be treated as human guinea pigs, mostly Chinese (including woman and children), but also Mongolians, Koreans, Russians and some British and American captured. At the end of the war, commander of Unit 731, Shiro Ishii, and most of his collegues were protected by US intelligence agencies, and in exchange for the results of the Unity research, covered by military secret, obtained immunity. The connections gained during the war paid off handsomely after the war for many members of the Ishii network. The Green Cross, a pharmaceutical company founded by Ishii staff Naito Ryoichi, Futagi Hideo, and Kitano Masaji, was a huge success after the war. Other Unit 731 members went on to success as well in other companies. Takeda Pharmaceutical Company, the Hayakawa Medical Company, the S.J. Company, Ltd., and the faculties of Tokyo University, Kyoto University, Osaka University, Kanazawa University, Showa University of Pharmacology, Nagoya Prefecture Medical University, Osaka Municipal University's School of Medicine, and Juntendo University along with several others employed former members of Unit 731 after the war. The Japanese government employed its share of Ishii graduates, including a chief of the Entomology section of the Health and Welfare Ministry's Preventive Health Research Laboratories and a director of Japan's National Cancer Center, as well as a president of Japan's Medical Association. There was also a surgeon general of Japan's newly minted Defense Force, and the list goes on. It is also noteworthy to mention that every director of the Japan National Institute of Health, beginning with its creation in May 1947 until 1983 (with only one exception), served in a biological warfare unit. Many Unit 731 men held other important positions in society and won many awards and achievements, while the lower workers, technicians, and soldiers melted back into Japanese society. Ishii Shiro never faced trial and died in quiet retirement of throat cancer in 1959, having lived out his remaining years on a stipend provided by the Japanese government because of his rank of Lieutenant General at the end of the war.

"I do not expect to publish any future work of mine which may do damage in the hands of irresponsible militarists ...", Norbert Wiener wrote in $1947^{46}$, admit-

${ }^{46}$ Wiener, N. (1947) A Scientist Rebels, The Atlantic Monthly. http://lanl-the-back-story.blogspot.it/2013/08/a-scientist-rebels.html 
ting his own ethical and professional responsibilities in lending himself to the game of the super partes scientist who works in the name of neutrality of science (denied by the facts), without worrying about the use that can be made, especially in contemporary hyper-technological society, of the results of his work.

An accommodating game that continues to be shared by many scientists, technicians, researchers, scholars, experts (mathematicians, engineers, biologists, chemists, physicists, psychologists, anthropologists, philosophers, genetics, etc.), but not all, as a testimony to the fact that the positivist priest-scientist should hang the cassock (the lab coat) to the nail, and assume his responsibilities.

Responsibilities which began to be perceived by insiders already from the Great War, when it outlined a world in which "For the first time in history, it has become possible for a limited group of a few thousand people to threaten the absolute destruction of millions" (Norbert Wiener, Moral Reflections of a Mathematician, 1956). This is the case, e.g., of Clara Immerwahr (1870-1915), German chemist and wife of German chemist Fritz Haber, considered the father of chemical warfare, tried in all ways to deter her husband from engaging in chemical weapons but was not successful and rather than assisting their use (during the First World War) committed suicide by firing at the heart at the age of 45 .

\subsection{Progressive Techno-Scientism and AI}

The following general definition of an animal: a system of different organic molecules that have combined with one another, under the impulsion of a sensation similar to an obtuse and muffled sense of touch given to them by the creator of matter as a whole, until each one of them has found the most suitable position for it shape and comfort.

Denis Diderot

On the Interpretation of Nature $(1753)^{47}$

And so we come to the post-war years, the Cold War years, during which the man-machine integration process, which until then had been identified with the assumption of the industrialization process, the mechanization of the production cycle, undergoes a true genetic mutation.

The machines diversify and exit the productive perimeter of industrial fields, where they have remained confined until then. They break into the homes and the lives of millions of Westerners, in the form of household appliances, cars, telephones, radio and television.

They become an integral part of consumers' (the baptismal name of a new neutral social category that brings together all of the social classes) home habitat, enter their lives and relationship dynamics, differ according to the tastes and expectations, creating the basis for what was to become a progressive, viral,

${ }^{47}$ As quoted in: Dingle, C.A. (2000) Memorable Quotations: French Writers of the Past, iUniverse, p. 64. 
techno-addiction.

An addiction to technological solutions that, over the years, become increasingly self-referential, more and more disconnected from the real needs of their users, increasingly bound by the laws of the Liberalist economic model and increasingly adhering to the Enlightenment myth of unlimited humanity's perfectibility.

During the ' 50 ', when global equilibrium depended on two super powers, United States and Soviet Union, three projects take shape: the manipulation of genetic material, the colonization of space and the creation of intelligent machines (something that might match the flying elephants of the cartoons, but with solid scientific bases).

The first project is outlined by the chromosomal theory of heritability (genetic material is DNA and not protein $\rightarrow$ Hershey-Chase, 1952) and the discovery of the molecular structure of DNA (J. Watson, F. Crick, M. Wilkins and R. Franklin, 1952). The second project was inaugurated when the Soviets launch the first artificial satellite in orbit around Earth, Sputnik 1 (1957). The third project begins when a young American mathematician, not yet thirty, John McCarthy, proposed to create a working group dealing with a new field of research, which he called Artificial Intelligence (1956).

A working group that, over the years, has assumed world proportions and that: is conducted by a range of scientists and technologists with varying perspectives, interests, and motivations. Scientists tend to be interested in understanding the underlying basis of intelligence and cognition, some with an emphasis on unraveling the mysteries of human thought and others examining intelligence more broadly. Engineering-oriented researchers, by contrast, are interested in building systems that behave intelligently. Some attempt to build systems using techniques analogous to those used by humans, whereas others apply a range of techniques adopted from fields such as information theory, electrical engineering, statistics, and pattern recognition. Those in the latter category often do not necessarily consider themselves AI researchers, but rather fall into a broader category of researchers interested in machine intelligence ${ }^{48}$.

Each of these three projects will be developed separately by both Americans and by Soviets, but it will be the US academic/industrial/military iron triangle, supported by an expanding mass media industry, who proved to be more forward looking and to have the greatest entrepreneurship when, in 1958, was established the Advanced Research Projects Agency (ARPA), heir of the Office of Scientific Research and Development (OSRD, created in 1941) and future Defense Advanced Research Projects Agency (DARPA, 1972), the government agencies of the US Department of Defense in charge of the development of new technologies for military use $\mathrm{e}^{49}$.

\footnotetext{
${ }^{48}$ In: Computer Science and Telecommunications Board, National Research Council (1999) Funding a Revolution. Government Support for Computing Research, Chapter 9, Developments in Artificial Intelligence. http://www.nap.edu/read/6323/chapter/11\#199

${ }^{49}$ In 2012 Russia has created a military agency similar to the US DARPA, the Advanced Research Foundation (ARF) and Defense Industry. China, Japan and South Korea are gearing up.
} 
The expression Artificial Intelligence, coined by McCarthy, indicates a promising new frontier of modern Information Theory. Information Theory is a discipline born in the Telecommunications field between the ' $20^{\mathrm{s}}$ and ' $30^{\text {s }}$ of the $20^{\text {th }}$ century, particularly thanks to the research and solutions in the military (encrypted and non-encrypted telecommunications) experienced during World War I, whose development and fortune is consolidated, again thanks to research and applications in the military, during World War II.

Decisive for the development of the contemporary version of the Information Theory, it has been the work conducted between the ' 40 ' and ' $50^{\text {s }}$ and separately by Claude Shannon (A Mathematical Theory of Communication, 1948) and by Norbert Wiener (Cybernetics or Control and Communication in the Animal and the Machine, 1948).

The term intelligence used to distinguish the new research frontier of Information Theory resurrects the same term employed by one of the pioneers of IT, Harry Nyquist of the American Telephone and Telegraph Company (AT \& T). In 1924 Nyquist publishes an article on the Bell System Technical Journal (BSTJ) entitled Certain Factors Affecting Telegraph Speed, where deals with the factors that affect the "maximum speed of transmission of intelligence". For those in the works of the period, the metaphorical term "intelligence" used by Nyquist for the transmission of an electromagnetic signal, appeared improper and misleading, compromised by anthropomorphic and psychological references incompatible with the subject matter. The transmission of signals between machines (coder/ decoder), i.e. the sending and receiving of variations of electromagnetic state through a medium (broadcast or via cable), it could not be in any way confused with the transmission of meaning (messages) neither could be associated with intellectual property such as the ability to learn, analyze, understand, communicate, plan, reasoning, hypothesize, draw conclusions, formulate abstract thoughts, solve problems, etc. Four years after the publication of Nyquist's article, a colleague of Bell Telephone Laboratories Inc., Ralph V.L. Hartley, published an article on the BSTJ, entitled Transmission of Information, where the intelligence metaphor is replaced, for reasons of "physical as contrasted with psychological considerations", by the metaphor information.

But what did Nyquist meant by the term intelligence? In fact anything that would have to deal with intellectual properties as those listed above, or that could attribute to a signal a semantic meaning. By the term intelligence, Nyquist refers to the statistically determined and decipherable component of a random signal (i.e. to the data inputs, conveyed and made available by an analogic signal, qualified by Nyquist as "the number of characters, representing different letters, figures, etc." transmitted in a certain period of time), whose transmissibility (with no loss of intelligence i.e. data) from a transmitting device (coder) to a receiver (decoder) depends on the degree of uncertainty resolution (associated with the noise inherently generated by the transmission medium or by the involved apparatuses) obtained in the signal transmission. 
AI it has been developed by Information Theory, Cybernetics and Computer Science in the telecommunications field, i.e. is built on feedback-loops algorithmic systems, which have nothing to do with human intelligence, but have much to do with the animal model described by Denis Diderot [On the Interpretation of Nature (1753)] and with the man conceived by Descartes [Treatise on Man (1633)].

At best, the performance of so-called intelligent machines is and will remain a simulation (rounded downward) of the skills manifested by a type of individuals affected by savant syndrome, or syndrome of the idiot savant, where idiot refers to an individual (generally male) with a series of more or less serious cognitive and mental delays, but having one or more of a super-developed capacity, typically the ability of computing and storage. This is all that an intelligent machine can and will aspire to do, Artificial Simulation of the Savant Syndrome (ASSS) [58].

If this is correct, why ASSS it is being passed off as AI?

Pursuing the development of man-machine hybrids, imagining them as a first step towards the production of artificial humanoids, programmed to be part of Cyber Physical Systems, interconnected by neural nets equipped with AI, is a project conceived and grown by contemporary progressive techno-scientism in the womb of positivism. AI is version 3.0 of the Cartesian "rational soup", that is: When a rational soul is present in this machine it will have its principal seat in the brain, and reside there like the fountain-keeper ${ }^{50}$. A project that does not renounce to conceive the human animal as a mechanical system, which, however complex it may be, it always boils down to a mosaic of tiles (building blocks). This means applying to res cogitans the same reductionist and mechanistic pattern applied by the positivist paradigm to res extensa: the structuring of the objects and phenomena that we observe inside and outside of us, happens thanks to a sequence of combinations (factorizable), guided by a code (algorithmic) among certain structural elements (building blocks). In the case of a material object, the structural elements can be molecules, atoms, particles. In the case of a fictitious object as intelligence can be, e.g., the logical-mathematical intelligence, the verbal i., the spatial i., the musical i., the kinesthetic i., the emotional i. (Howard Gardner), in turn decomposable into sub-groups, and so on and so forth. Once broken down into objectifiable structural elements, the object shall be subjected to measuring and eventually reproduced and controlled. The result is a puzzle composed by many elements, connected to joint, in a frame which develops a given function.

\subsection{Towards the Robotization of Society}

As scientific understanding has grown, so our world has become dehumanised. Man feels himself isolated in the cosmos, because

${ }^{50}$ Descartes, Treatise on Man, 1633, $\$ 131$.

https://www.colorado.edu/neh2015/sites/default/files/attached-files/descartes-treatise_on_man.pdf 
he is no longer involved in nature and has lost his emotional "unconscious identity" with natural phenomena. These have slowly lost their symbolic implications. (...) No voices now speak to man from stones, plants, and animals, nor does he speak to them believing they can hear. His contact with nature has gone, and with it has gone the profound emotional energy that this symbolic connection supplied.

Carl Gustav Jung Man and His Symbols $(1964)^{51}$

Between the ' $60^{\text {s }}$ and ' 90 ', $\mathrm{AI}$, whose mission is "designing systems that exhibit the characteristics associated with human intelligence, such as understanding language, learning, reasoning, solving problems, and so on", motivated by the conviction that "every aspect of learning or any other feature of intelligence can in principle be so precisely described that a machine can be made to simulate it", becomes an integral part of nascent computer science (the Internet, date of birth 1983, is the evolution of a DARPA creation for military use [59], the ARPAnetwork, 1969).

In the ' $90^{\text {s, }}$, the know-how gained during the ' $80^{\text {s }}$ by computer science, cybernetics, robotics and AI research came to the realization of a project called Strategic Computing Program (SCP), funded both by public funds (from the Federal Defense Research Projects Agency, DARPA), and by private investors (such as IBM's industrial giant, Dragon Systems, BBN, Bolt Beranek and Newman, and SDC, Systems Development Corporation), which will create the so-called intelligent machines, namely: machine with advanced intelligence technology and high-performance computing, including speech recognition and understanding, natural-language computer interfaces, vision comprehension systems, and advanced expert systems development, provided by a significant increasing in computer performance, through parallel-computer architectures, software, and supporting microelectronics.

But the ' $90^{\text {s }}$ are also the years marked by the collapse of the Berlin Wall and, with it, by the collapse of international equilibriums and national identities, drawn by the Cold War and its deployments. The iron arm between the United States of America and the Union of Soviet Socialist Republics ends with the implosion and abandonment of the field by the latter, and the bipolar world is suddenly unipolar.

The new era is greeted by the "first postmodern war of history" (Jean-François Lyotard), the First War of the Gulf (1990), a war that did not take place (Jean Baudrillard), where conventional weapons are the backdrop to the use of new and sophisticated technological solutions (Cyberwar, Infowar, Technowar, Antiwar, Postmodernwar) [60], developed to transform the soldier into a semi-human operator, integrated with external equipments (which will soon be integrated ${ }^{51}$ Jung, C.G. (1968) Man and His Symbols, Dell Publishing, p. 85. 
with internal devices), capable of enhancing combat capabilities, supported by a network of remote-controlled warhead devices that can turn war zones into platforms for as many video games. Virtual Arenas where people really die.

Thanks to electronic simulation technologies, the massive power of mass media transforms wars into small and big screen performances, Hollywood-style sub-products, super reality shows, super-video games, super-saga of semi-human superheroes fighting Evil for the Good of the world.

The First Gulf War it has been just a taste of the hyper-technological wars that are waiting for us in the near future, where human soldiers will gradually be replaced by robotic armaments flanked by man-machine hybrids, i.e. cyborg-soldiers [61], the Extra-Integrated Man-Machine Hybrid (EIMMH) born for military purposes, the cyborg model designed for combat, the elder brother of the Normo-Integrated Man-Machine Hybrid (NIMMH), designed for civilian purposes.

It thus officially begins the man-machine dis-integration process.

Equipped with an internal device inserted in dwelling, e.g. an intracranial nanorobot or a microchip for neural interaction (brain-computer interfaces) ${ }^{52}$, or a simple subcutaneous chip (transponder implantation), making him or her parametrizable (real-time detection and transmission of physiological and environmental parameters) and identifiable (automatic acquisition of all data relating to its identity, its movements and location), the NIMMH will be able to interact, at work, at home, at school, in public places, etc., via Near Field Communication (NFC) or via Far Field Communication (FFC) [62], with a Cyber-Physical System (which it can include any external electronic device with a wireless or bluetooth system and a dedicated interface, which exposes the subject to the risk of hacking).

Different will be the extra-integrated cyborg (EIMMH), a man-machine hybrid trained and designed to deal with high-risk experiences (military missions, police or espionage operations, terrorist or criminal acts, space travel and stays in extra-terrestrial environments) which, besides being supplemented by internal technological components as those of the normo-integrated model, can expand some self-regulating body-mind functions (such as tolerance to pain, hunger and thirst, thermoregulation, etc.), enhance certain normal performances (such as computing ability, memory and perceptual capabilities), and interfacing with military CPSs equipped with robotic systems such as the already existing Modular Advanced Armed Robotic System (MAARS), the already operational Lethal Autonomous Weapons Systems (LAWS) [63], the Taranis (fully automated combat aircraft, already operational), the FLA (Fast Lightweight Autonomy, DARPA project), the CODE (Collaborative Operations in Denied Environment, DARPA project), etc.

The use of integrated systems consisting in EIMMHs and robotic CPSs, marks the passage from the phase of computerization of war (and society) to the phase

${ }^{52}$ See: J. G. Fleischer, G.M. Edelman, Brain-based devices: An embodied approach to linking nervous system structure and function to behavior, Ieee Robotics and Automation Magazine, 2009. http://www.nsi.edu/ fleischer/fleischer_edelman_ram.pdf 
of robotization of war (and society): I see a greater robotization [of war], in fact, future warfare will involve operators and machines (...) They would be integrated into large comprehensive reconnaissance-strike system. The soldier would gradually turn into an operator and be removed from the battlefield [Lieutenant General Andrey Grigoriev, Russian Advanced Research Foundation (ARF), 2016].

\subsection{The Universal Consciousness of Neo-Positivism}

Eugenics and the rampant post-human subculture promote the study, elaboration and adoption of scientific methods aimed at perfecting the human being, i.e. aimed at the promotion of physical and mental characteristics considered positive or eugenic (fit), and the removal of those considered negative or dysgenic (unfit) through the selection and manipulation of individuals or their parts (operations that in the past were carried out using traditional techniques for livestock farming and agriculture, which today can rely on high-tech communication marketing, on sophisticated technological devices and on increasingly effective central and peripheral neuro-engineering, and genetic, molecular, cellular, tissue, and organ bio-engineering).

Both make use of "working conditioning" techniques and mass media tools to influence individual and collective behavior, in order to create the belief that human capital is useful insofar as it is subordinate to the scientific-technical and technological capital.

Post-human subculture integrates Eugenics hope in the scientific and selective perfectibility of humanity, with the use of a very advanced technical and technological armament.

The computed-programmed-coded relationship (IT language $\rightarrow$ algorithmic feed back loops) that elapses between the conditioned ( $\rightarrow$ software) and unconditional ( $\rightarrow$ hardware) variables of the hybrid man-machine or of the robot $(\rightarrow$ technological birth), gives rise to behavioral dynamics largely (cyborg) or totally (robots) deterministic and reliable, namely controllable-predictable-reproduceblereversible.

For this reason, the man-machine hybrid, the anthropomorphic robot and the humanoid are clearly preferable (fit, superior, stronger, more suitable) to the unfit-natural-man.

Eugenics and post-human subculture are intertwined by the equivalence ratio which lies between the progressive techno-scientism of the late $19^{\text {th }}$ century $(\rightarrow$ Eugenics) and progressive techno-scientism of the late $20^{\text {th }}$ century $(\rightarrow \mathrm{AI})$.

An equivalence ratio that can be expressed as follows: Eugenics is to Mendelian theory (theory of the transmission mode of hereditary characters, Johann Gregor Mendel, 1866) and Darwinian theory (the theory of the linear, progressive and ascending evolution of biological systems, Charles Darwin, 1859) as Artificial Intelligence is to i) chromosomal theory of heritability (the genetic material is made up of DNA and not of proteins, Hershey-Chase, 1952), ii) the dis- 
covery of the molecular structure of DNA (J. Watson, F. Crick, M. Wilkins and R. Franklin, 1952), and iii) Information Theory, the theory born by convergence between cybernetic theory, or theory of communication and of control systems in artificial systems and in living beings (Norbert Wiener, 1948), and the theory of information's transmission mode (Claude Shannon, 1948).

It has been a hundred years since the General Theory of Relativity (GR) introduced the notion of spacetime, which radically changed the way of thinking about the time and space of Newtonian physics, and since Quantum Mechanics (QM) has radically changed the way of conceiving energy/matter, but no one yet knows what spacetime is nor what energy is ("It is important to realize that in physics today, we have no knowledge of what energy is", Richard Feynman, The Feynman Lectures on Physics, Vol. I, page 4-1).

However, the fact that no one knows what spacetime is and what energy is, has not prevented from measuring, describing and using phenomena that are related to one and the other.

The physical dimension we are part of is no longer the one described by classical physics, and the strange phenomena that are emerging from the quantum and relativistic dimension are fueling a growing and often unwise interest in the psychic dimension, the fictitious dimension that the science of res extensa had excluded a priori from his own field of investigation.

An almost morbid interest, which, both inside and outside the scientific world, exploits the dangerous combination of hyper-technological techno-centrism and the spiritual drift of the West (but also of the East and of the rest of the world!).

A West, which seems to hold little to warnings like those made by Richard Feynman "I think I can safely say that nobody understands Quantum Mechanics.", (The Character of Physical Law, Cambridge, Massachusetts, 1967), or by Niels Bohr "There is no quantum world. There is only an abstract physical description. It is wrong to think that the task of physics is to find out how nature is. Physics concerns what we can say about nature ...". So that: "Quantum mechanics is often quoted as the explanation for many things, because it's so weird that people latch onto it as a hope, to explain everything that they would like to believe about the universe ... Quantum mechanics is a replacement for the phrase "anything goes". Once anything goes, you can have anything you want. So what better thing to have than something that gives you everything you want? The point is, with quantum mechanics, everything doesn't go. On certain scales, for certain times, in certain regions, everything goes and strange things happen. But it's not true for the universe at large" (Bo Gardiner).

The two souls of Enlightenment, excited by the syncretism that has developed between the strangeness of some phenomena described by QM or GR and the strangeness that emerge from categories of reality generated in other places and at other times, by other human communities, through forms of knowledge other than that adopted by modern science (e.g. by Buddhism, Taoism, Shamanism), 
are allying with each other to deliver a new, flamboyant, secular religion, where the Supreme Being, in the art Deus otiosus, alias Deus Absconditus, is called Universal Consciousness.

One of the promising religion incubators currently available on the world market of scientific spirituality, is called Science and Nonduality (SAND) ${ }^{53}$, a post-materialist international community founded in 2009 by Mrs. Zaya and Mr. Maurizio Benazzo (she's from Bulgaria, he's Italian), whose annual conference has become a meeting place for preeminent scientists, philosophers, spiritual teachers, and mystics to explore the new paradigm emerging in spirituality and grounded in cutting-edge science. Among its supporters and sympathizers, grouped in 2014 around a Manifesto ${ }^{54}$, is the California Institute of Integral Studies (CIIS) $)^{55}$, where you can attend a Master in Consciousness Studies; the Californian Department of Psychology at John F. Kennedy University, which has started a Master in Consciousness and Transformative Studies ${ }^{56}$; and the Schumacher College, based in Totnes, England, which offers a Master in Holistic Science ${ }^{57}$.

Robespierre declared himself supreme priest of the Supreme Being. Auguste Comte proclaimed himself the supreme pontiff of the Positivist Church. Francis Galton established tribunals of the Inquisition of the Positivist Church.

Who will be the Grand Master of the nascent Church of Universal Consciousness?

\section{Conclusions}

\section{Artificial intelligence is the future not only of Russia but of all of mankind. \\ There are huge opportunities, but also threats}

\footnotetext{
${ }^{53}$ Nonduality is the philosophical, spiritual, and scientific understanding of non-separation and fundamental intrinsic oneness. For thousands of years, through deep inner inquiry, philosophers and sages have come to the realization that there is only one substance and we are therefore all part of it. This substance can be called Awareness, Consciousness, Spirit, Advaita, Brahman, Tao, Nirvana or even God. It is constant, ever present, unchangeable and is the essence of all existence. https://www.scienceandnonduality.com/about/nonduality/

${ }^{54} \mathrm{We}$ are a group of internationally known scientists, from a variety of scientific fields (biology, neuroscience, psychology, medicine, psychiatry), who participated in an international summit on post-materialist science, spirituality and society. The summit was co-organized by Gary E. Schwartz, $\mathrm{PhD}$ and Mario Beauregard, $\mathrm{PhD}$, the University of Arizona, and Lisa Miller, PhD, Columbia University. This summit was held at Canyon Ranch in Tucson, Arizona, on February 7-9, 2014. http://opensciences.org/about/manifesto-for-a-post-materialist-science

${ }^{55}$ See: https://www.ciis.edu/

${ }^{56}$ The Master of Arts in Consciousness and Transformative Studies program provides a 58-unit curriculum with courses that challenge students' beliefs, examine the relationship between consciousness and the world, and explore new possibilities for personal, social, and global transformation. https://www.jfku.edu/Programs-and-Courses/College-of-Psychology/Consciousness-Transformative -Studies/Programs/MA-Consciousness-and-Transformative-Studies.html See also:

http://opensciences.org/blogs/open-sciences-blog/online-ma-program-in-consciousness-transforma tive-studies

${ }^{57}$ See:

https://www.schumachercollege.org.uk/courses/postgraduate-courses/holistic-science/holistic-scienc e-programme
} 
that are difficult to foresee today ... the industry leader [in this sphere] will rule the world.

Vladimir Putin ${ }^{58}$

Pursuing the development of man-machine hybrids, imagining them as a first step towards the production of artificial humanoids, believed to be better than humans (Ray Kurzweil, chief engineer of Google, theorizes the exceeding of human intelligence by computer): can it be considered a project that resurrects Eugenics in a post-human form? Maybe.

Certainly, to hypothesize, as the scientific mainstream does, the creation of conscious-minded machines, is the tangible sign of a scientific and intellectual shorting that does not promise anything good.

What can be done, and is already underway, is to have new technological persuasive and dissuasive tools, including robotic and IT systems that leverage AI, both military and civil, as a means for market expanding and control, or as a deterrent to resolve conflicts related to it, both locally and globally, on small and large scale.

The noble uses of the new technologies, such as those in the field of medicine, will serve as a deterrent to the affirmation of less noble one.

Progressive Techno-Scientism 4.0, with its science-fiction scenarios, marks the apogee of the man-machine integration process and the point of break in the relationship of coexistence and convenience between the man-naturally-conceived $(\rightarrow$ psychological birth) and man-artificially-built ( $\rightarrow$ technological birth): the relationship is no longer sustainable and is no longer convenient. At stake is the annihilation of mankind.

The man-machine integration process is turning into a man-machine disintegration process: "Unlike other potential manifestations of AI which still remain in the realm of science fiction, autonomous weapons systems are on the cusp of development right now and have a very real potential to cause significant harm to innocent people along with global instability." (Ryan Gariepy, founder \& CTO of Clearpath Robotics ${ }^{59}$ )

\section{References}

[1] Messori, C. (2015) Quale Modello per le Neuroscienze - Part. I of III. [Which Model for Neuroscience.] Il Minotauro, Persiani Editore, Bologna, 1, 25-45.

https://www.researchgate.net/publication/278414562_Quale_Modello_per_le_Neur oscienze

[2] Rose, F. (1984) Into the Heart of the Mind: An American Quest for Artificial Intelligence. Harper \& Row, New York, 36.

\footnotetext{
${ }^{58}$ TASS, 1 September 2017, Putin stresses whoever takes the lead in artificial intelligence will rule world. http://tass.com/society/963209

${ }^{59}$ See:

https://futureoflife.org/2017/08/20/killer-robots-worlds-top-ai-robotics-companies-urge-united-nati ons-ban-lethal-autonomous-weapons/
} 
[3] Wiener, N. (1954) Men, Machines, and the World About. In: Galderston, I., Ed., Medicine and Science, New York Academy of Medicine and Science, International Universities Press, New York, 13-28.

http://21stcenturywiener.org/wp-content/uploads/2013/11/Men-Machines-and-theWorld-About-by-N.-Wiener.pdf

[4] Dennis, M.A. (2000) Vannevar Bush. American Engineer, Encyclopedia Britannica. https://www.britannica.com/biography/Vannevar-Bush\#ref192589

[5] Mosse, G.L. (2003) Il razzismo in Europa. [Racism in Europe. From Origins to Holocaust.] Dalle origini all'olocausto, Editori Laterza, Roma-Bari, 18.

[6] Messori, C. (2012) Dalla Facoltà Acustico-Musicale alle Origini del Linguaggio Orale Fino al Predominio della Cavità Orale che Genera il Mondo sulla Cavità Uterina che Genera la Vita. [From the Acoustic-Musical Faculty to Oral Language Origins, up to the Predominance of Oral Cavity Which Generates the World on the Uterine Cavity Which Generates Life.] Il Minotauro, Persiani Editore, Bologna, 2, 6-43.

https://www.researchgate.net/publication/255696745_Dalla_Facolta_Acustico-Musi cale_alle_Origini_del_Linguaggio_Orale_Fino_al_Predominio_della_Cavita_Orale_ che_Genera_il_Mondo_sulla_Cavita_Uterina_che_Genera_la_Vita

[7] Messori, C. (2016) From Continuity to Contiguity. On the Genesis of Consciousness, Culture and Oral Language - Part I-II-III-IV. Journal of Consciousness Exploration \& Research, 7, 163-228.

https://www.researchgate.net/publication/295857703_From_Continuity_to_Contig uity_On_the_genesis_of_consciousness_culture_and_oral_language_Part_I_of_IV

[8] Messori, C. (2015) Quale Modello per le Neuroscienze - Part II of III. [Which Model for Neuroscience.] Il Minotauro, Persiani Editore, Bologna, 2, 80-117.

https://www.researchgate.net/publication/278414562_Quale_Modello_per_le_Neur oscienze

[9] Messori, C. (2013) Near Death Experience nell'Epoca di Transizione da Homo Technologicus a Homo Artificialis. [Near Death Experience in the Age of Transition from Homo Technologicus to Homo Artificialis.] Il Minotauro, Persiani Editore, Bologna, 2, 6-56.

[10] Messori, C. (2000) Il Sole e la Luna. Sulla Natura dei Simboli e della Mente Umana. [The Sun and the Moon. On the Nature of Symbols and Human Mind.] Federico Ceratti Editore, Milan, Italy.

https://www.researchgate.net/publication/255696883_Il_Sole_e_la_Luna_Sulla_Nat ura_dei_Simboli_e_della_Mente_Umana

[11] Messori, C. (2004) Le Metamorfosi della Meraviglia. Riflessioni sui Percorsi della Conoscenza dall'Età del Bronzo ad Oggi. [The Metamorphoses of Wonderment. Reflections on the Paths of Knowledge from the Bronze Age to Present Day.] Maremmi Editori, Firenze Libri, Firenze, Italy.

https://www.researchgate.net/publication/255696858_Le_Metamorfosi_della_Mera viglia

[12] Hayek, F.A. (1946) The Road to Serfdom. George Routledge \& Sons LTD, London, 68.

[13] Minois, G. (2007) Storia dell'avvenire. [History of the Future. From Prophets to Futurology.] Dai profeti alla futurologia. Edizioni Dedalo, Bari.

[14] Caritat de Condorcet, M.J.A.N. (1794) Outlines of an Historical View of the Progress of the Human Mind, Tenth Epoch, Future Progress of Mankind. http://oll.libertyfund.org/titles/condorcet-outlines-of-an-historical-view-of-the-pro gress-of-the-human-mind\#lf0878_head_013 
[15] Tang, L., et al. (2017) CRISPR/Cas9-Mediated Gene Editing in Human Zygotes Using Cas9 Protein. Molecular Genetics and Genomics, 292, 525-533. https://doi.org/10.1007/s00438-017-1299-Z

[16] Liang, P., et al. (2015) CRISPR/Cas9-Mediated Gene Editing in Human Tripronuclear Zygotes. Protein Cell, 6, 363-372. https://doi.org/10.1007/s13238-015-0153-5

[17] Regalado, A. (2015) Engineering the Perfect Baby. Scientists Are Developing Ways to Edit the DNA of Tomorrow's Children. Should They Stop before It's Too Late? MIT Technology Review.

https://www.technologyreview.com/s/535661/engineering-the-perfect-baby/

[18] Cyranoski, D. and Reardon, S.S. (2015) Chinese Scientists Genetically Modify Human Embryos, Nature.

http://www.nature.com/news/chinese-scientists-genetically-modify-human-embryo s-1.17378\#/b1

[19] Moxon, K.A. and Foffani, G. (2015) Brain-Machine Interfaces beyond Neuroprosthetics. Neuron, 86, 55-67.

http://www.cell.com/neuron/fulltext/S0896-6273(15)00260-3?_returnURL=http\%3 A\%2F\%2Flinkinghub.elsevier.com\%2Fretrieve\%2Fpii\%2FS0896627315002603\%3Fs howall\%3Dtrue https://doi.org/10.1016/j.neuron.2015.03.036

[20] Liu, J., et al. (2015) Syringe-Injectable Electronics. Nature Nanotechnology, 115, 1-36. https://cml.harvard.edu/assets/NatNano_2015_10_629-636_Liu_SI.pdf https://doi.org/10.1038/nnano.2015.115

[21] Lee, W., et al. (2015) Image-Guided Transcranial Focused Ultrasound Stimulates Human Primary Somatosensory Cortex. Scientific Reports, 5, 8743.

https://www.ncbi.nlm.nih.gov/pmc/articles/PMC4348665/ https://doi.org/10.1038/srep08743

[22] Edward, D., et al. (2013) Physiological and Modeling Evidence for Focal Transcranial Electrical Brain Stimulation in Humans: A Basis for High-Definition tDCS. Neuroimage, 7, 266-275. https://www.ncbi.nlm.nih.gov/pmc/articles/PMC4359173/ https://doi.org/10.1016/j.neuroimage.2013.01.042

[23] Herrmann, C.S., et al. (2013) Transcranial Alternating Current Stimulation a Review of the Underlying Mechanisms and Modulation of Cognitive Processes. Frontiers in Human Nauroscience, 7, 279. http://journal.frontiersin.org/article/10.3389/fnhum.2013.00279/full

[24] Legon, W., et al. (2014) Transcranial Focused Ultrasound Modulates the Activity Of Primary Somatosensory Cortex in Humans. Nature Neuroscience, 2, 322-329. https://www.researchgate.net/publication/259699619_Transcranial_focused_ultraso und_modulates_the_activity_of_primary_somatosensory_cortex_in_humans https://doi.org/10.1038/nn.3620

[25] Liu, G., et al. (2015) Syringe Injectable Electronics. Nat Nanotechnol., 10, 629-636. https://www.ncbi.nlm.nih.gov/pmc/articles/PMC4591029/ https://doi.org/10.1038/nnano.2015.115

[26] Shuhmann, T.G. Jr., et al. (2017) Syringe-Injectable Electronics with a Plug-and-Play Input/Output Interface. Nano Letters, 17, 5836-5842. https://doi.org/10.1021/acs.nanolett.7b03081

[27] Mueller, J. (2014) Transcranial Focused Ultrasound Modulates Intrinsic and Evoked EEG Dynamics. Brain Stimulation, 7, 900-908. http://www.brainstimjrnl.com/article/S1935-861X(14)00306-4/fulltext 
https://doi.org/10.1016/j.brs.2014.08.008

[28] Sanger, M. (1922) The Pivot of Civilization, from Chapter VI and VIII. http://groups.csail.mit.edu/mac/users/rauch/abortion_eugenics/sanger/

[29] Cohen, H. (2016) Imbeciles: The Supreme Court, American Eugenics, and the Sterilization of Carrie Buck. Penguin Press, London.

[30] Galton, F. (1883) Inquiries into Human Faculty and Its Development. Macmillan and Co., London. https://doi.org/10.1037/14178-000

[31] Harward College Library (1914) Eugenics: Twelve University Lectures. By Morton Arnold Aldrich, William Herbert Carruth, Charles Benedict Davenport, William Henry Howell, Arthur Holmes, Harvey Ernest Jordan, Albert Galloway Keller, Edward Lee Thorndike, Victor Clarence Vaughan, Herbert John Webber, Robert Henry Wolcott, Charles Abram Ellwood, Ed., Dodd Mead and Company, New York. https://ia801409.us.archive.org/10/items/eugenicstwelveu00ellwgoog/eugenicstwelv eu00ellwgoog.pdf

[32] Barondess, J.A. (1998) The Old Eugenics and the New Science. Transactions of the American Clinical and Climatological Association, 109, 174-182

https://www.ncbi.nlm.nih.gov/pmc/articles/PMC2194351/

[33] Garland, E.A. (2001) Essays on Science and Society. Is a New Eugenics Afoot? Science, 294, 59-61. http://science.sciencemag.org/content/294/5540/59.full https://doi.org/10.1126/science.1066325

[34] Krige, J. and Pestre, D. (2013) Science in the Twentieth Century. Routledge, Abingdon-on-Thames.

[35] Stone, R. and Hunt, S.J. (2017) The Bush Crime Family: The Inside Story of an American Dynasty. Skyhorse Publishing Inc., New York.

[36] Farber, S.A. (2008) U.S. Scientists' Role in the Eugenics Movement (1907-1939): A Contemporary Biologist's Perspective. Zebrafish, 5, 243-245.

https://www.ncbi.nlm.nih.gov/pmc/articles/PMC2757926/ https://doi.org/10.1089/zeb.2008.0576

[37] Kimmelman, B.A. (1983) The American Breeders' Association: Genetics and Eugenics in an Agricultural Context, 1903-13. Social Studies of Science, 13, 163-204. https://doi.org/10.1177/030631283013002001

[38] Spiro, J.P. (2009) Defending the Master Race: Conservation, Eugenics, and the Legacy of Madison Grant. University Press of New England (UPNE), Lebanon.

[39] Purdy, J. (2015) After Nature: A Politics for the Anthropocene. Harvard University Press, Cambridge, Massachusetts, 181. https://doi.org/10.4159/9780674915671

[40] Black, E. (2012) War against the Weak: Eugenics and America's Campaign to Create a Master Race. Science and Society, Expanded Edition, Dialog Press.

[41] Allen, G.E. (2004) Was Nazi Eugenics Created in the US? Book Review: War against the Weak: Eugenics and America's Campaign to Create a Master Race. Science and Society, 5, 451-452 https://www.ncbi.nlm.nih.gov/pmc/articles/PMC1299061/

[42] Kay, L.E. (1993) The Molecular Vision of Life: Caltech, The Rockefeller Foundation, and the Rise of the New Biology. Oxford University Press, Oxford.

[43] Masterjohn, C. (2009) The Rockfeller Foundation's Molecular Vision of Life-How the Aims of Eugenics, Social Control, and Human Engineering Shaped Molecular Biology and 20th Century Science. A Review of Lily E. Kay's The Molecular Vision of Life: Caltech, The Rockefeller Foundation, and the Rise of the New Biology (Oxford University Press, 1993). 
[44] Jones, E. and Rahman, S. (2008) The Maudsley Hospital and the Rockefeller Foundation: The Impact of Philanthropy on Research and Training. Journal of the History of Medicine and Allied Sciences, 64, 273-299.

https://www.ncbi.nlm.nih.gov/pmc/articles/PMC2723762/ https://doi.org/10.1093/jhmas/jrn065

[45] Kuhl, S. (2002) The Nazi Connection: Eugenics, American Racism, and German National Socialism. Oxford University Press, Oxford.

[46] Braund, J. and Sutton, D.G. (2008) The Case of Heinrich Wilhelm Poll (1877-1939): A German-Jewish Geneticist, Eugenicist, Twin Researcher, and Victim of the Nazis. Journal of the History of Biology, 41, 1-35.

[47] Rabson, S.M. (1936) Alfred Grotjahn, Founder of Social Hygiene. Bulletin of the New York Academy of Medicine, 12, 43-58.

https://www.ncbi.nlm.nih.gov/pmc/articles/PMC1965908/pdf/bullnyacadmed00856 -0007.pdf

[48] Willich, S.N. and Berghöfer, A. (2013) George Wolff (1886-1952): Spreading the Legacy of Alfred Grotjahn to the United States. American Journal of Public Health, 103, 2202-2203. https://www.ncbi.nlm.nih.gov/pmc/articles/PMC3828972/ https://doi.org/10.2105/AJPH.2013.301365

[49] Kevles, D.J. (2013) From Eugenics to Genetic Manipulation. In: Krige, J. and Pestre, D., Eds., Science in the Twentieth Century, Chapter 16. Routledge, Abingdon-on-Thames.

[50] Aron, R. (2004) L'avvenire delle religioni secolari. [The Future of Secular Religions.] (1944) In: Forti, S., Ed., La filosofia di fronte all'estremo, Totalitarismo e riflessione filosofica [The Philosophy behind the Extreme. Totalitarianism and Philosophical Reflection], Einaudi, Torino, 4.

[51] Cassier, E. (1973) La filosofia dell'Illuminismo. [The Enlightenment Philosophy.] (1932) La Nuova Italia, Firenze.

[52] Talmon, J.L. (2000) Le origini della democrazia totalitarian. [The Origins of Totalitarian Democracy.] (1952) Il Mulino, Bologna.

[53] Monnerot, J. (1970) Sociologia del comunismo. [Sociology of Communism.] (1949) Giuffrè Editore, Milano.

[54] Sironneau, J.-P. (1995) Crisi religiosa dei Lumi e secolarizzazione. [Religious Crisis of the Enlightenment and Secularization.] In: Boschi, U., Cheng, A., Clemént, O., Cosi, D.M., Sfameni Gasparro, G., Margolin, G.-C., Massein, P., Paolini, L., Ries, J., Sironneau, J.-P., Eds., Crisi, rotture e cambiamenti [Crises, Breaks and Changes], Trattato di Antropologia del Sacro [Anthropology Treatise of the Sacred], Editoriale Jaca Book, Milano, Vol. 4, 337-338.

http://www.gianfrancobertagni.it/materiali/varia/riescrisi.pdf

[55] Gold, H. (2004) Unit 731: Testimony. Tuttle Publishing, North Clarendon, Vermont.

[56] Sheldon, H.H. (2002) Factories of Death: Japanese Biological Warfare in 1932-45 and the American Cover-Up. Routledge, Abingdon-on-Thames.

[57] Williams, P. and Wallace, D. (1990) Unit 731: Japan's Secret Biological Warfare in World War II. Grafton Books, London.

[58] Messori, C. (2016) Intelligence vs Artificial Intelligence: The King is Naked. Open Access Library Journal, 3: e3115. https://www.scirp.org/Journal/PaperInformation.aspx?PaperID=72003

[59] Kay, L.E. (2000) Who Wrote the Book of Life? A History of the Genetic Code, 
Stanford University Press, Redwood City, CA.

[60] Gray, C.H. (1998) Postmodern War: The New Politics of Conflict. The Guilford Press, New York.

[61] Gray, C.H. (2002) Cyborg Citizen: Politics in the Posthuman Age. Routledge, Abingdon-on-Thames.

[62] Agbinya, J.I. (2011) Principles of Inductive Near Field Communications for Internet of Things. River Publishers, Aalborg, Denmark.

[63] Bieri, M. and Dickow, M. (2014) Lethal Autonomous Weapons Systems: Future Challenges. Publikationen des Center for Security Studies (CSS), Switzerland.

Submit or recommend next manuscript to OALib Journal and we will provide best service for you:

- Publication frequency: Monthly

- 9 subject areas of science, technology and medicine

- Fair and rigorous peer-review system

- Fast publication process

- Article promotion in various social networking sites (LinkedIn, Facebook, Twitter, etc.)

- Maximum dissemination of your research work

Submit Your Paper Online: Click Here to Submit

Or Contact service@oalib.com 